\title{
Partitioning the effects of changes in nitrate availability and phytoplankton community structure on relative nitrate uptake
}

\author{
Jesús M. Mercado ${ }^{1, *}$, Teodoro Ramírez ${ }^{1}$, Dolores Cortés ${ }^{1}$, Marta Sebastián $^{2}$, \\ Esperanza Liger ${ }^{3}$, Begoña Bautista ${ }^{2}$
}

${ }^{1}$ Instituto Español de Oceanografía, Centro Oceanográfico de Málaga, Puerto Pesquero s/n, Apdo. 285, 29640 Fuengirola (Malaga), Spain

${ }^{2}$ Departamento de Ecología, Universidad de Málaga, Facultad de Ciencias, Campus Universitario de Teatinos, 29074 Malaga, Spain

${ }^{3}$ Departamento de Física Aplicada II, Universidad de Málaga, E.T.S.I. Informática, Campus de Teatinos s/n, 29071 Malaga, Spain

\begin{abstract}
The uptake of dissolved nitrogen by different assemblages of phytoplankton was determined during 4 seasonal surveys carried out in the northwest sector of the Alboran Sea. The study area was characterized by stratification of the water column from spring to autumn, leading to very low nutrient concentrations in the euphotic zone; in particular, nitrate was below the detection limit at numerous stations in autumn. In winter and spring, the potential limitation of phytoplankton growth by nitrate was alleviated at some stations by upwelling of the nutrient-enriched Levantine Intermediate Water (LIW). The values of relative $\mathrm{NO}_{3}{ }^{-}$uptake (the proportion of nitrate to total $\mathrm{N}$ uptake) were highly variable (ranging from 0.01 to 0.8 ), even during single surveys. At most of the sampling stations during the stratification period, the relative nitrate uptake was $<0.2$ at the surface, but increased at the depth of the sub-surface chlorophyll a fluorescence maximum (SFM). At the surface, relative nitrate uptake and nitrate concentrations were strongly correlated, and about $82 \%$ of the relative nitrate uptake variability was accounted for by simultaneous changes in the nitrate concentrations and the micro-plankton chlorophyll a size fractions. These changes were related to modifications in upwelling intensity, as determined by variability in surface salinity. In contrast, relative nitrate uptake was not correlated with nitrate concentrations in the SFM samples, where the mean nitrate concentration increased 3-fold with respect to the surface value. On average, the micro-phytoplankton in these samples collected at the SFM was dominated by diatoms, the abundance of which ranged from 24 to 960 cells $\mathrm{ml}^{-1}$. This variability in diatom cell abundance explained about $52 \%$ of the variability of relative nitrate uptake at this depth level. Therefore, our data demonstrate that the proposed relationship between relative nitrate uptake and large phytoplankton was most evident at non-limiting nitrate concentrations.
\end{abstract}

KEY WORDS: Nitrogen uptake · Diatoms · Phytoplankton · Primary production · Upwelling · Alboran Sea $\cdot$ Mediterranean Sea

\section{INTRODUCTION}

The new production in the ocean is driven by the input of allochthonous nitrogen $\left(\mathrm{NO}_{3}{ }^{-}\right.$and $\left.\mathrm{N}_{2}\right)$ into the euphotic zone (contrary to the regenerated production based on the use of recycled nitrogen, i.e. $\mathrm{NH}_{4}^{+}$and urea; Dugdale \& Goering 1967). Therefore, the new production should be predominant where upwelling of nutrient-enriched water occurs (i.e. geostrophic fronts and upwelling systems). On the one hand, high new production rates have been described in coastal regions during episodes of wind-induced upwelling (Harrison et al. 1987, Owens et al. 1993). The influence of the phytoplankton community structure on the new 
production is widely recognised, as the relation of new to total production ( $f$-ratio) is often higher for large-sized phytoplankton than for small-sized phytoplankton (Harrison \& Wood 1988). A relationship between the $f$-ratio and relative biomass of large-sized phytoplankton has been described (Tremblay et al. 1997). It has been proved that mesoscale physical phenomena causing the injection of nutrients into the euphotic zone favour the growth of large-sized phytoplankton (Goldman 1993). However, under certain circumstances, uncoupling between new-nutrient supply and phytoplankton growth response could happen (L'Helguen et al. 2002). On the other hand, low newproduction rates (L'Helguen et al. 2002) and/or high regenerated production rates have been described in some frontal systems (McCarthy \& Nevins 1986, LeCorre et al. 1993, Videau et al. 1994). Moreover, the relationship between nitrate concentration and new production (as estimated from the $f$-ratio) is often missed (Le Bouteiller 1986, Probyn 1988, Dortch \& Postel 1989, Glibert et al. 1991, Dauchez et al. 1996, Watts \& Owens 1999). These results could reflect the importance of the physiological state of the cells in determining nitrogen uptake rates and new production, as suggested by Dauchez et al. (1996). In fact, some studies (e.g. MacIsaac et al. 1985) have shown changes in $\mathrm{NO}_{3}{ }^{-}$uptake rates normalized by biomass during different phases of a coastal bloom induced by upwelling, which suggests changes in the structural use of assimilated nitrate (Dugdale \& Wilkerson 1991).

The objective of the present study was to investigate the coupling between the supply of nitrate towards the euphotic zone, the phytoplankton community structure and the nitrogen uptake at several sampling stations located in the northwestern Alboran Sea subjected to episodic upwelling events. This area is characterized by the presence of a surface layer of nutrientpoor Atlantic water (SAW) entering through the Strait of Gibraltar and a layer of Levantine Intermediate Water (LIW), which flows out below the SAW (Minas et al. 1991, Ramírez et al. 2005). Episodically, LIW reaches the upper layer of the water column. Consequently, high chlorophyll a (chl a) concentrations are commonly observed in this area (Minas et al. 1991, Rodríguez et al. 1997, García-Górriz \& Carr 2001). The intensity of the upwelling is subject to seasonal variability linked to changes in the inflow and outflow through the Strait of Gibraltar (García-Lafuente et al. 2000, Gómez et al. 2000) and/or to the thermal stratification (Mercado et al. 2007). Besides, the variability of the local wind regime induces short-term modifications in the upwelling intensity (Cano \& Lafuente 1991). As mentioned above, the nutrient signatures of SAW and LIW are quite different, as SAW is often depleted in $\mathrm{N}$ relative to $\mathrm{P}$, while the N:P ratio in LIW is considerably higher (Mercado et al. 2005, Ramírez et al. 2005, 2006, Reul et al. 2005). Therefore, it can be postulated that the $\mathrm{NO}_{3}{ }^{-}$ supply towards the surface layer, fuelled by LIW upwelling, would enhance the new production in the northwestern area of the Alboran Sea. In addition, a coupling between new production and seasonal and short-term hydrographic variability could be expected.

\section{MATERIALS AND METHODS}

Sampling stations, hydrographic data, nutrients and chl a concentrations. Hydrographic data (temperature and salinity) and seawater samples were collected at 6 stations located in the northwestern Alboran Sea (western Mediterranean Sea) during 4 cruises performed in July 2003, October 2003, February 2004 and May 2004 (Fig. 1). Unfortunately, the sampling at Stns 5 and 6 could not be carried out during the spring cruise due to adverse weather conditions. A vertical profile of temperature, salinity and chl $a$ fluorescence was obtained at each station with a CTD Seabird 25 equipped with a fluorescence probe (Seapoint 6000). The mixed-layer (ML) depth was estimated according to the method proposed by Kara et

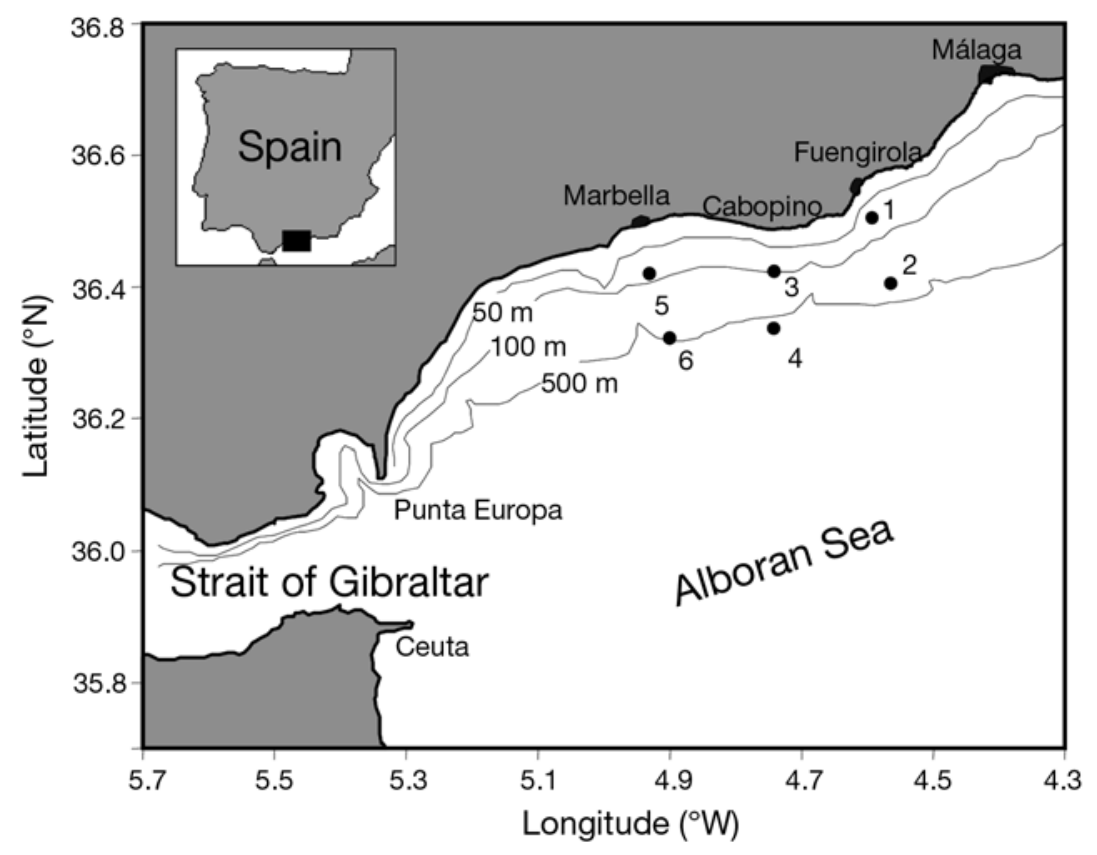

Fig. 1. Location of the sampling stations 
al. (2000) based on the use of a finite difference criterion, where the ML depth is the depth where potential density has changed by a fixed amount from the surface reference value. Specifically, we calculated the ML depth as that at which the density difference from the surface was 0.5. This threshold was used as it gave the best fit for finding the proper pycnocline (as determined from visual inspection of the density profiles). The depth of the Atlantic-Mediterranean interface (AMI) at each station was estimated from the vertical position of the 37.5 isohaline (Rodríguez et al. 1998).

Samples of seawater were collected with Niskin bottles at 6 fixed depths $(0,10,20,50,75$ and $100 \mathrm{~m})$ within the upper $100 \mathrm{~m}$ layer. Additionally, another sample was collected at the depth where the sub-surface chl a fluorescence maximum (SFM) was detected, usually positioned between 20 and $50 \mathrm{~m}$ depth. Two sub-samples of $10 \mathrm{ml}$ of seawater were frozen from each depth, in order to determine nutrient concentrations (nitrate plus nitrite, nitrite, phosphate and silicic acid) by means of segmented flow analysis using a Bran-Luebbe AA3 autoanalyser, following the methods described in Ramírez et al. (2005). The detection limits for $\mathrm{NO}_{3}{ }^{-}+\mathrm{NO}_{2}{ }^{-}, \mathrm{NO}_{2}{ }^{-}, \mathrm{PO}_{4}{ }^{3-}$ and $\mathrm{Si}(\mathrm{OH})_{4}$ were $0.05,0.05,0.04$ and $0.10 \mu \mathrm{M}$, respectively. $\mathrm{NH}_{4}{ }^{+}$concentrations were estimated following Grasshoff et al. (1983). Urea concentration was measured in the samples used for the N-uptake experiments according to Goeyens et al. (1998), following an adaptation of the method by Mulvenna \& Savidge (1992). The concentration of urea was below the analytical method detection limit $(0.1 \mu \mathrm{M})$ in most of the analysed samples. A volume of 0.5 to $1 \mathrm{l}$ of seawater was filtered through Whatman GF/F filters and frozen until their analysis in the laboratory, in order to determine total chl a $\left(\mathrm{chl}_{\mathrm{t}} \mathrm{a}\right)$ by fluorometry (Yentsch \& Menzel 1963), after extraction in $90 \%$ acetone overnight at 4 to $5^{\circ} \mathrm{C}$. Euphotic zone depth $\left(z_{\mathrm{e}}\right.$, the depth at which the downwelling photosynthetically active radiation (PAR) is reduced to $1 \%$ of its value at the surface) was derived from the chl a concentration profiles following the numerical method proposed by Morel \& Berthon (1989), which is based on the following equation:

$$
z_{\mathrm{e}}=568.2\left[\mathrm{chl}_{\mathrm{t}} \mathrm{a}\right]^{-0.746}
$$

Phytoplankton community structure. The size-fractioned chl a concentration was estimated in the surface and the SFM depth samples, i.e. the samples used for the incubation experiments (during spring, when the SFM was not detected clearly, the phytoplankton community structure and the incubation experiments were performed with the samples collected at $10 \mathrm{~m}$ depth).
The microplankton chl a size fraction $(>20 \mu \mathrm{m})$ was estimated by using polycarbonate $20 \mu \mathrm{m}$ Albet filters. The nano-phytoplankton chl a size fraction was calculated by subtracting the microplankton chl a size fraction from the amount of chl a retained by $2 \mu \mathrm{m}$ Millipore polycarbonate filters. The chl a size fraction from 0.7 to $2 \mu \mathrm{m}$ was calculated by subtracting the microand nanoplankton chl a fractions from the amount of chlorophyll retained on $0.7 \mu \mathrm{m}$ Whatman GF/F filters $\left(\mathrm{chl}_{\mathrm{t}} \mathrm{a}\right)$. This chl a size fraction was called pico-phytoplankton, although it has to be noted that some picoplankton cells could have a smaller size than $0.7 \mu \mathrm{m}$ and were therefore not quantified in our analysis. Additionally, the abundance of larger phytoplankton cells was determined following the sedimentation technique of Utermohl (1958). A volume of 100 to $200 \mathrm{ml}$ of the fixed samples was settled in chambers for 48 to $72 \mathrm{~h}$ and afterwards analysed using a Leica inverted microscope. Different fields were counted until at least 100 cells of the most abundant species were recorded (Ros \& Miracle 1984). Subsequently, the bottom of the chamber was inspected in order to record the larger size species.

${ }^{15} \mathbf{N}$ incubation experiments. Nitrogen uptake experiments were performed using seawater samples collected at both the surface and the depth of the SFM, although a single sample was used at some stations during the winter survey. Note that the $\mathrm{N}$ uptake experiments could not be done at Stn 5 in autumn. The samples were incubated for $2 \mathrm{~h}$ in $1 \mathrm{l}$ polycarbonate transparent bottles in light-attenuated deck boxes, cooled by flowing surface seawater. The incubation period duration was selected according to the results of $2 \mathrm{~N}$-uptake time-course experiments which demonstrated nitrogen uptake was linear during the first 2 to $3 \mathrm{~h}$ of incubation. Before the incubations, additions of potassium nitrate- $\mathrm{N}^{15}$ (99 atomic percent [at.\%] $\left.{ }^{15} \mathrm{~N}\right)$, ammonium- $\mathrm{N}^{15}$ sulphate (98 at. $\left.\%{ }^{15} \mathrm{~N}\right)$, or urea-N ${ }^{15}\left(99\right.$ at. $\left.\%{ }^{15} \mathrm{~N}\right)$ were performed (0.05 $\mu \mathrm{M}$ final concentration). The final $\mathrm{N}$-enrichment varied from $<1$ to $100 \%$. Controls (i.e. samples without addition of ${ }^{15} \mathrm{~N}$ ) were also incubated. The isotope enrichment and the concentration of the particulate organic nitrogen (PON) was estimated at the beginning of the experiment by filtering 11 of initial nonincubated seawater (i.e. without ${ }^{15} \mathrm{~N}$ added) through Whatman GF/F filters. After incubation, the samples were filtered through precombusted $\left(450^{\circ} \mathrm{C}\right.$ for $2 \mathrm{~h}$ ) Whatman GF/F filters. The filters were frozen until they were exposed to $\mathrm{HCl}$ fumes overnight and then dried and pelletized for isotopic analysis. Nitrogen stable isotope natural abundance measurements were made by continuous flow isotope-ratio mass spectrometry. This technique also provided data of particulate organic carbon (POC) and nitrogen (PON). After 
incubation, aliquots of the bottles were collected in order to measure the $\mathrm{NO}_{3}{ }^{-}, \mathrm{NH}_{4}{ }^{+}$and urea concentrations. $\mathrm{NO}_{3}{ }^{-}$and $\mathrm{NH}_{4}{ }^{+}$concentrations were estimated as described above. Urea uptake rates were not calculated for the samples where urea concentrations were not detectable. The calculations of nitrogen uptake were performed following Knap et al. (1996). The initial PON concentration was used for the calculations, as it varied on average $<10 \%$ after incubation. The main problem in calculating in situ uptake rates in our experiments was that the addition of ${ }^{15} \mathrm{~N}$ increased the nitrogen concentration $>10 \%$ in some samples. This could lead to an overestimation of the nitrogen uptake rates (Dugdale \& Goering 1967). For these samples, the uptake rates were corrected following the procedure proposed by MacIsaac \& Dugdale (1972). Another problem inherent to the ${ }^{15} \mathrm{~N}$ uptake experiments is the possible change of the isotope enrichment of ammonium and urea during incubation due to $\mathrm{N}$ regeneration (dilution effect). The potential underestimation of the $\mathrm{NH}_{4}{ }^{+}$and urea uptake rates was evaluated following the numerical procedure proposed by Kanda et al. (1987). It was assumed that uptake and regeneration rates were tightly coupled (i.e. we assumed a value of 1 for parameter $a$ in Eq. 8 in Kanda et al. 1987). According to the results of these calculations, the underestimation of the uptake rates was $<5 \%$ in most of the samples (the samples in which the underestimation could be higher than this value have been marked with an asterisk in Fig. 8 'Results'). The relative nitrate uptake was estimated as the ratio of $\mathrm{NO}_{3}{ }^{-}$uptake to $\mathrm{NO}_{3}{ }^{-}+\mathrm{NH}_{4}{ }^{+}+$urea uptakes (when measurable) .

Statistical analysis. The estimated variables were expressed as the mean value \pm standard deviation (SD). Significant differences among means were tested at $\mathrm{p}<0.05$ with a Kruskal-Wallis $H$-test (Zar 1984). The relationship between variables was studied by Pearson's correlation analysis. Similarities among physical, chemical and biological variables were analysed by principal component analysis (PCA; Savenkoff et al. 1995, Packard et al. 2000). Two PCAs were performed with the surface and SFM samples. In the first case, the variables were: ML and AMI depths, $\mathrm{NO}_{3}{ }^{-}, \mathrm{Si}(\mathrm{OH})_{4}, \mathrm{PO}_{4}{ }^{3}$ concentrations, ratios of $\mathrm{NO}_{3}{ }^{-}$to dissolved inorganic nitrogen (DIN), DIN to $\mathrm{P}$ and $\mathrm{Si}$ to $\mathrm{P}$, and total and size-fractioned chl $a$. In the SFM samples, the variables were: ML and AMI depths, $\mathrm{NO}_{3}{ }^{-}, \mathrm{Si}(\mathrm{OH})_{4}$ and $\mathrm{NH}_{4}{ }^{+}$concentrations, the ratio of $\mathrm{NO}_{3}{ }^{-}$to DIN, total and size-fractioned chl $a_{\text {, }}$ and cell, diatom and dinoflagellate abundances. Before performing the PCA, variables were transformed by subtracting the mean and dividing by the SD. The software STATISTICA 7 (StatSoft, 1984-2005) was used for the analysis.

\section{RESULTS}

\section{Hydrographic variability}

At all the stations, the temperature and salinity profiles (Fig. 2) indicate the presence of a permanent halocline and thermocline that separate the SAW (featured by salinity of 36.4 according to Parrilla \& Kinder 1987) and the LIW underflowing. Nevertheless, the vertical position of the 37.5 isohaline (AMI) varied both spatially and during the seasonal cycle (Table 1). Surface salinity (SS) measured at the different stations and cruises was negatively correlated with the AMI depth $(\mathrm{r}=-0.80, \mathrm{p}<0.001, \mathrm{n}=22)$. SS was $<36.4$ at some stations sampled in summer (Stns 4 and 6). These low salinity values were associated with relatively low surface temperatures (especially at Stn 4). In spite of this hydrographic variability, the water column was strongly stratified at the 6 sampling stations during summer, when the ML thickness ranged from 13 to $22 \mathrm{~m}$. Surface salinity was less variable in autumn, when it averaged 36.56 (Table 1), indicating that the surface layer in the study area was occupied by slightly modified SAW. Accordingly, AMI was located at about $59 \mathrm{~m}$ deep in autumn (Table 1). SS in winter and spring was significantly higher than in summer and autumn.

The thickness of the $z_{\mathrm{e}}$ changed significantly throughout the seasonal cycle (Table 1 ). Thus, $z_{\mathrm{e}}$ averaged $30 \mathrm{~m}$ in summer, increased steeply in autumn, and decreased progressively from winter to spring (Table 1, see also Fig. 5). Consequently, $z_{\mathrm{e}}$ spread beyond the ML in summer and autumn, while it matched the lower limit of the ML in winter and spring.

\section{Nutrient concentrations and their molar ratios}

In summer, winter and spring, $\mathrm{NO}_{3}{ }^{-}$accounted for about $80 \%$ of the dissolved inorganic nitrogen in the ML (DIN, as the sum of $\mathrm{NO}_{3}{ }^{-}, \mathrm{NO}_{2}^{-}$and $\mathrm{NH}_{4}{ }^{+} ;$Table 2). During these surveys, a significant relative contribution of $\mathrm{NH}_{4}{ }^{+}$to DIN (about $70 \%$ ) was only obtained in some surface samples collected at Stn 1 in summer and at Stns 2 and 3 in spring (Fig. 3). Contrastingly, $\mathrm{NO}_{3}{ }^{-}$ contribution to DIN at the ML was reduced significantly in autumn (Table 2). The vertical profiles of $\mathrm{NO}_{3}{ }^{-}$indicate the presence of a strong vertical gradient at most stations during summer, autumn and spring (Fig. 3). However, the gradients were less prominent in winter, due to the lack of thermal stratification. The position of the nitracline varied widely, although it was usually located close to the lower limit of the ML. Only at some stations in summer (Stn 1) and autumn (Stns 1, 3,4 and 5) was the nitracline located below the ML. 

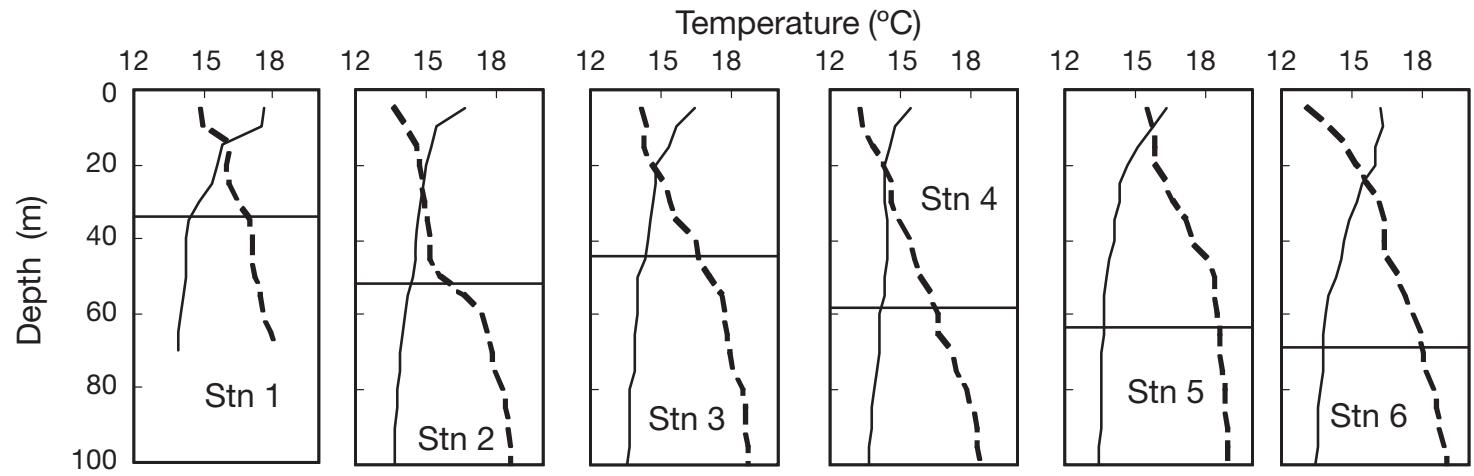

Summer
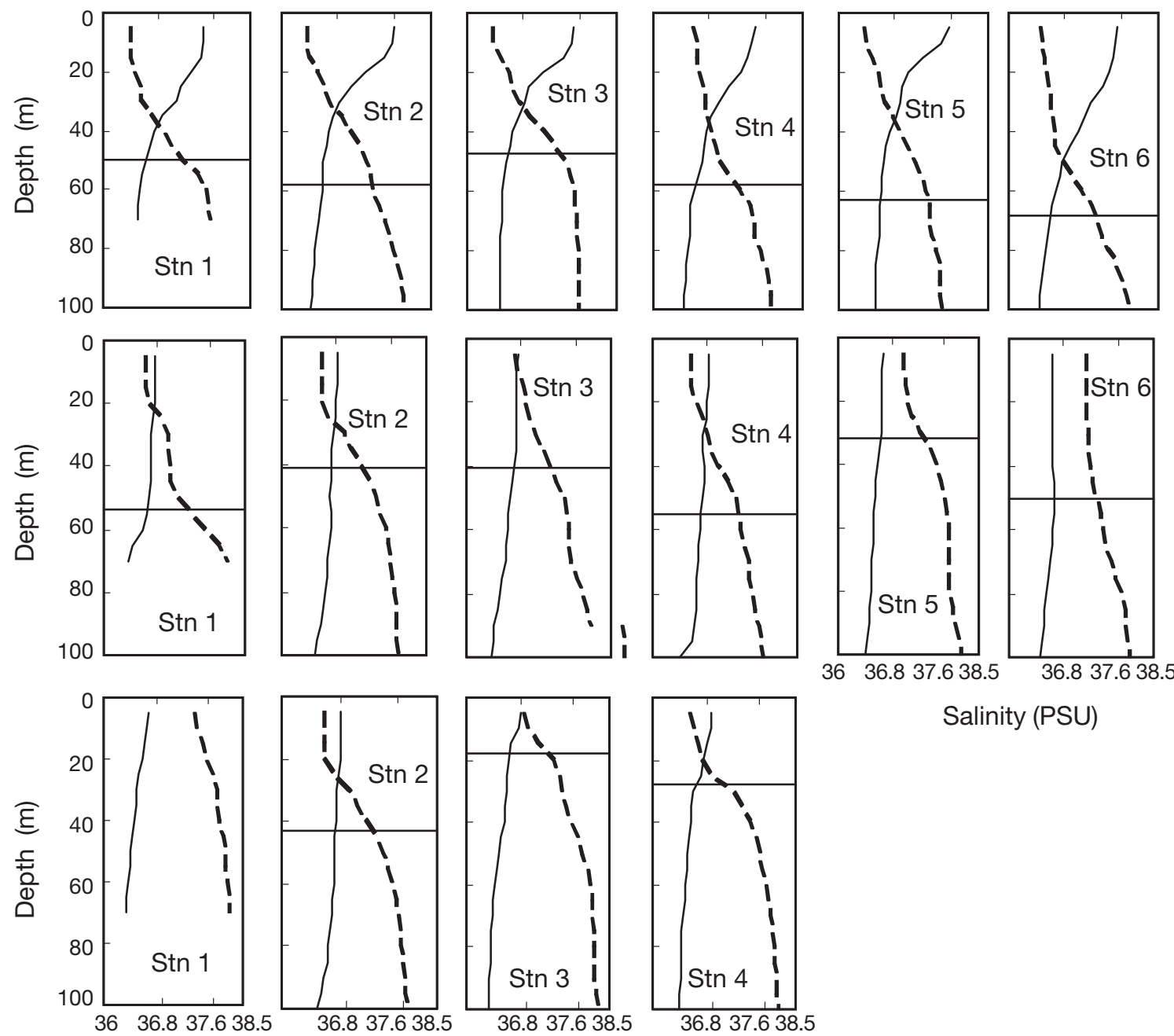

Salinity (PSU)

Winter

Spring

Salinity (PSU)

Fig. 2. Temperature (continuous lines) and salinity (dashed lines) profiles at the sampling stations. Horizontal line indicates the position of the 37.5 isohaline (Atlantic-Mediterranean interface)

When all the $\mathrm{NO}_{3}{ }^{-}$profiles were compared, the mean concentration of $\mathrm{NO}_{3}{ }^{-}$within the $\mathrm{ML}$ and the distance between the AMI and ML were negatively correlated $(\mathrm{r}=-0.66, \mathrm{p}<0.001, \mathrm{n}=22)$, suggesting that the upwelling of the LIW led to the injection of $\mathrm{NO}_{3}{ }^{-}$ towards the surface layer.
The $\mathrm{NO}_{2}^{-}$concentration showed marked variations among seasons and stations, although, on average, it represented $<5 \%$ of the DIN (Table 2). The depth of the maximal $\mathrm{NO}_{2}{ }^{-}$concentration was located below the ML in summer and autumn, the mean $\mathrm{NO}_{2}^{-}$concentration being lower within the ML than in the deeper 
Table 1. Seasonal means $( \pm \mathrm{SD})$ of the hydrographic variables. ST: surface temperature, upper $20 \mathrm{~m}$ water layer temperature $\left({ }^{\circ} \mathrm{C}\right)$; SS: surface salinity, salinity of the upper $20 \mathrm{~m}$ water layer; ML: mixed layer thickness (m); AMI: depth of the Atlantic-Mediterranean interface $(\mathrm{m}) ; z_{\mathrm{e}}$ : euphotic zone depth $(\mathrm{m})$. For each row, significant differences among medians were tested at $\mathrm{p}<0.05$ with a Kruskal-Wallis $H$-test

\begin{tabular}{|lccccc|}
\hline & Summer & Autumn & Winter & Spring & $p$ \\
\hline ST & $15.69 \pm 0.64$ & $17.23 \pm 0.26$ & $14.75 \pm 0.29$ & $14.81 \pm 0.31$ & $<0.001$ \\
SS & $36.80 \pm 0.25$ & $36.56 \pm 0.09$ & $36.93 \pm 0.28$ & $37.08 \pm 0.48$ & 0.05 \\
ML & $18 \pm 4$ & $22 \pm 6$ & $46 \pm 15$ & $25 \pm 6$ & 0.002 \\
AMI & $49 \pm 15$ & $59 \pm 9$ & $44 \pm 8$ & $23 \pm 18$ & 0.01 \\
$z_{\mathrm{e}}$ & $30 \pm 7$ & $53 \pm 5$ & $37 \pm 5$ & $26 \pm 4$ & 0.01 \\
\hline
\end{tabular}

Table 2. Seasonal means $( \pm \mathrm{SD})$ of nutrients $(\mu \mathrm{M})$ and nutrient molar ratios $(\mathrm{N}$, nitrate + nitrite + ammonium) in the mixed layer. For each row, significant differences among medians were tested at $\mathrm{p}<0.05$ with a Kruskal-Wallis $H$-test. nd: not detectable

\begin{tabular}{|lccccc|}
\hline & Summer & Autumn & Winter & Spring & $\mathrm{p}$ \\
\hline $\mathrm{NO}_{3}{ }^{-}$ & $2.1 \pm 1.1$ & $0.3 \pm 0.6$ & $2.4 \pm 1.7$ & $1.9 \pm 1.9$ & 0.01 \\
$\mathrm{NO}_{2}{ }^{-}$ & $0.04 \pm 0.03$ & $0.05 \pm 0.07$ & $0.12 \pm 0.03$ & $0.10 \pm 0.08$ & 0.008 \\
$\mathrm{NH}_{4}{ }^{+}$ & $0.18 \pm 0.12$ & $0.20 \pm 0.26$ & $0.14 \pm 0.16$ & $0.15 \pm 0.09$ & 0.87 \\
$\mathrm{Si}(\mathrm{OH})_{4}$ & $1.31 \pm 0.76$ & $0.73 \pm 0.49$ & $2.13 \pm 0.67$ & $1.70 \pm 0.92$ & 0.04 \\
$\mathrm{PO}_{4}{ }^{3-}$ & $0.12 \pm 0.07$ & $0.06 \pm 0.03$ & $0.11 \pm 0.03$ & $0.11 \pm 0.06$ & 0.04 \\
$\mathrm{Urea}$ & $0.08 \pm 0.1$ & $0.10^{\mathrm{a}}$ & nd & nd & \\
$\mathrm{N}: \mathrm{P}$ & $9.8 \pm 5.9$ & $5.0 \pm 5.1$ & $13.3 \pm 3.9$ & $13.5 \pm 5.9$ & 0.01 \\
$\mathrm{~N}: \mathrm{Si}$ & $1.4 \pm 0.7$ & $0.7 \pm 0.5$ & $1.2 \pm 0.4$ & $1.5 \pm 0.4$ & 0.007 \\
$\mathrm{Si}: \mathrm{P}$ & $11.5 \pm 2.6$ & $10.7 \pm 5.5$ & $20.0 \pm 5.2$ & $15.4 \pm 3.0$ & 0.77 \\
& & & & \\
${ }^{a} \mathrm{Ur}$ ma & & & & \\
\hline
\end{tabular}

layer. On the contrary, the vertical distribution of $\mathrm{NO}_{2}^{-}$ was more homogenous in winter (with the exception of Stn 5), when its mean concentration within the ML was significantly higher than in summer and autumn. In spring, the vertical maximum of $\mathrm{NO}_{2}{ }^{-}$was located within the ML. With respect to $\mathrm{NH}_{4}{ }^{+}$, there was no common vertical variation pattern in summer and autumn, as the $\mathrm{NH}_{4}{ }^{+}$maximum appeared to be located irrespective of the ML position. However, $\mathrm{NH}_{4}{ }^{+}$concentration was higher within the ML than in the deeper layer in winter and spring. The urea concentration was only determined in the surface and SFM samples. The highest urea concentration $(0.42 \mu \mathrm{M})$ was obtained in the surface layer of Stn 6 during summer, when it averaged $0.1 \mu \mathrm{M}$ (Table 2). In contrast, urea was detected only in 1 sample during autumn (surface sample at Stn 2) and was undetectable in winter and spring.

The vertical distribution of $\mathrm{Si}(\mathrm{OH})_{4}$ was similar to that described for $\mathrm{NO}_{3}^{-}$(data not shown). On average, the $\mathrm{Si}(\mathrm{OH})_{4}$ concentration in the ML decreased in autumn and increased in winter and spring (Table 2). The vertical profiles of $\mathrm{PO}_{4}^{-3}$ (Fig. 4) also indicated the occurrence of a vertical gradient, although it was less steep than for $\mathrm{NO}_{3}{ }^{-}$and $\mathrm{Si}(\mathrm{OH})_{4}$. The seasonal variation pattern of $\mathrm{PO}_{4}^{-3}$ in the ML was also similar to that obtained for $\mathrm{NO}_{3}{ }^{-}$and $\mathrm{Si}(\mathrm{OH})_{4}$, being reduced significantly in autumn (Table 2). Contrastingly, the lowest $\mathrm{PO}_{4}^{-3}$ concentration below the ML was obtained in winter (Fig. 4).

The N:P ratio, estimated by dividing DIN by $\mathrm{PO}_{4}{ }^{-3}$ concentration (Fig. 4), varied spatially and seasonally. In summer, the lowest N:P ratio was obtained in the surface layer. The N:P ratio increased rapidly with depth, reaching values higher than the Redfield ratio (16:1; Redfield et al. 1963) at the bottom of the ML. In contrast, the N:P ratio was significantly lower than the Redfield ratio in all the samples collected within the ML during autumn. In winter and spring, the N:P ratios obtained for the whole water column were similar or higher than the Redfield ratio (with the exception of the surface sample collected at Stn 1 in spring). Consequently, the lower $\mathrm{N}: \mathrm{P}$ ratio averaged for $\mathrm{ML}$ was obtained in autumn (Table 2). The seasonal variation pattern for the $\mathrm{Si} P$ ratio in the ML was very close to that described for the N:P ratio (Table 2), as it decreased significantly in autumn. The N:Si ratio was in general higher than 1:1 (the optimal ratio reported for diatoms by Brzezinski 1985) in the ML during summer, winter and spring, although it was lower than 1:1 in autumn (Table 2).

These data suggest that an impoverishment of $\mathrm{NO}_{3}{ }^{-}$ and $\mathrm{Si}(\mathrm{OH})_{4}$ relative to $\mathrm{PO}_{4}^{-3}$ was produced at the surface layer at Stns 1, 3, 4 and 5 in summer and throughout the ML at all stations sampled in autumn. In contrast, exhaustion of $\mathrm{NO}_{3}{ }^{-}$was only detected at Stn 2 in spring. In spite of this seasonal cycle, when averaged values within the ML were pooled together, a negative correlation between the N:P ratio and the distance between the AMI and the lower limit of the ML was obtained $(\mathrm{r}=-0.72, \mathrm{n}=22, \mathrm{p}<0.001)$. This indicates that the $\mathrm{NO}_{3}{ }^{-}$relative to $\mathrm{PO}_{4}{ }^{-3}$ deficit was diminished by the shallower position of the AMI. In contrast, the relationship between the AMI position and N:Si or Si:P ratios was not statistically significant.

\section{Chl a distribution}

Most vertical profiles of $\mathrm{chl}_{\mathrm{t}}$ a concentration (Fig. 5) indicated the presence of a sub-surface maximum, the 


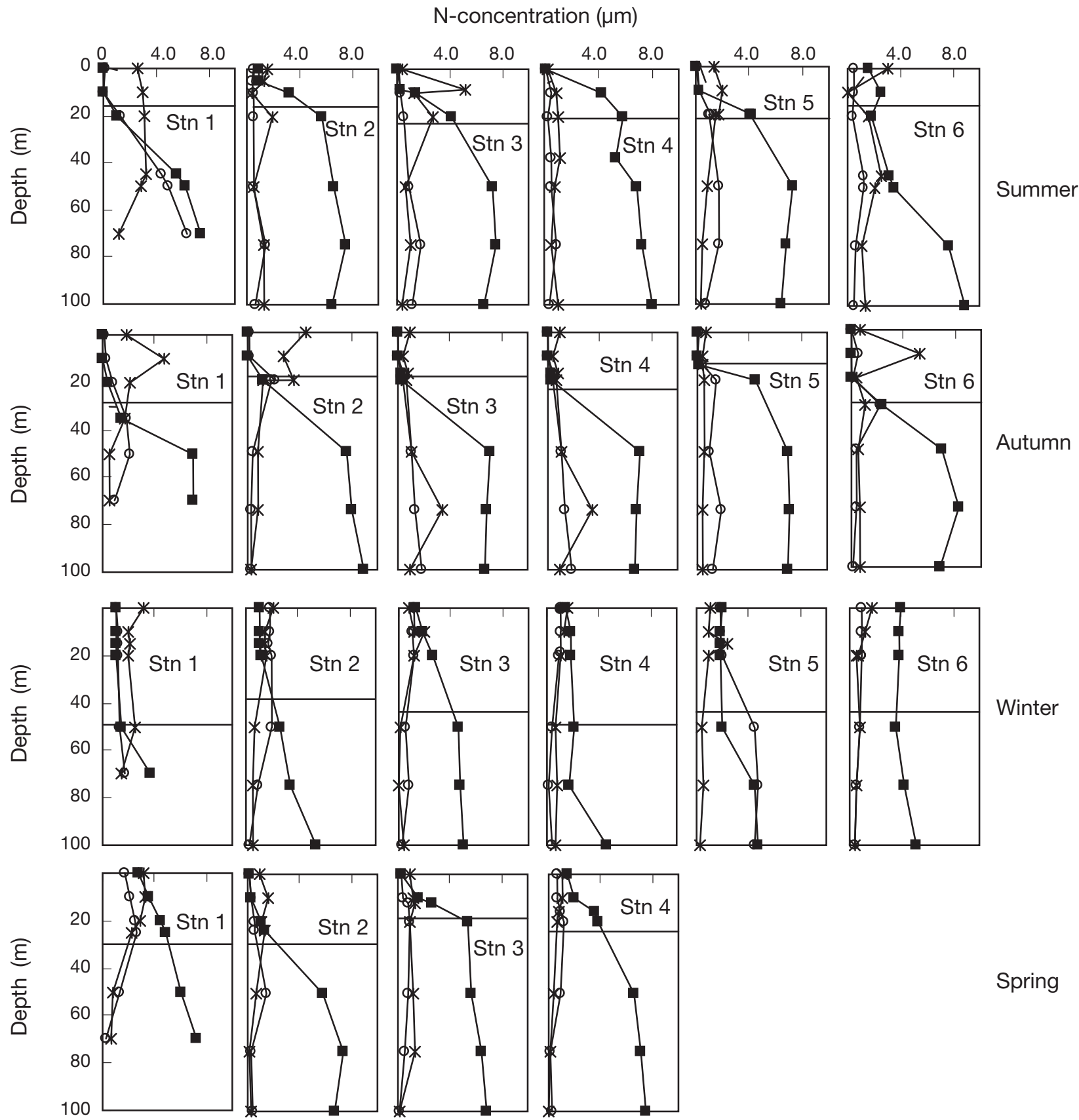

Fig. 3. Nitrate (ם), nitrite $(O)$ and ammonium $(*)$ concentration profiles at the sampling stations. Horizontal line indicates the lower limit position of the mixed layer

position of which matched the SFM depth in all profiles (data of fluorescence are not shown). The $\mathrm{chl}_{\mathrm{t}}$ a concentration at the SFM varied seasonally (Fig. 5), ranging from $2.5 \mathrm{\mu g} \mathrm{l}^{-1}$ in autumn and winter to $7.5 \mathrm{\mu g} \mathrm{l}^{-1}$ in summer. The seasonal and spatial variability of the SFM depth was also prominent, especially in summer, when the SFM depth ranged from $40 \mathrm{~m}$ at Stns 1 and 6 (i.e. it was located below the ML) to $5-10 \mathrm{~m}$ at Stns 2 and 3 (Fig. 5). In autumn, the SFM tended to be located close to the lower limit of the ML, while it was situated within the ML in winter. In spring, the $\mathrm{chl}_{\mathrm{t}}$ a maxima were located at the surface.

A positive correlation between $\mathrm{chl}_{\mathrm{t}} \mathrm{a}$ and $\mathrm{NO}_{3}{ }^{-}$concentration within the ML was obtained when all the stations and seasons were considered $(r=0.65, p<$ $0.001, \mathrm{n}=22$ ). The correlation between $\mathrm{chl}_{\mathrm{t}} \mathrm{a}$ and $\mathrm{PO}_{4}{ }^{-3}$ concentration was also statistically significant $(r=0.51$, $\mathrm{p}=0.01, \mathrm{n}=22$ ). 


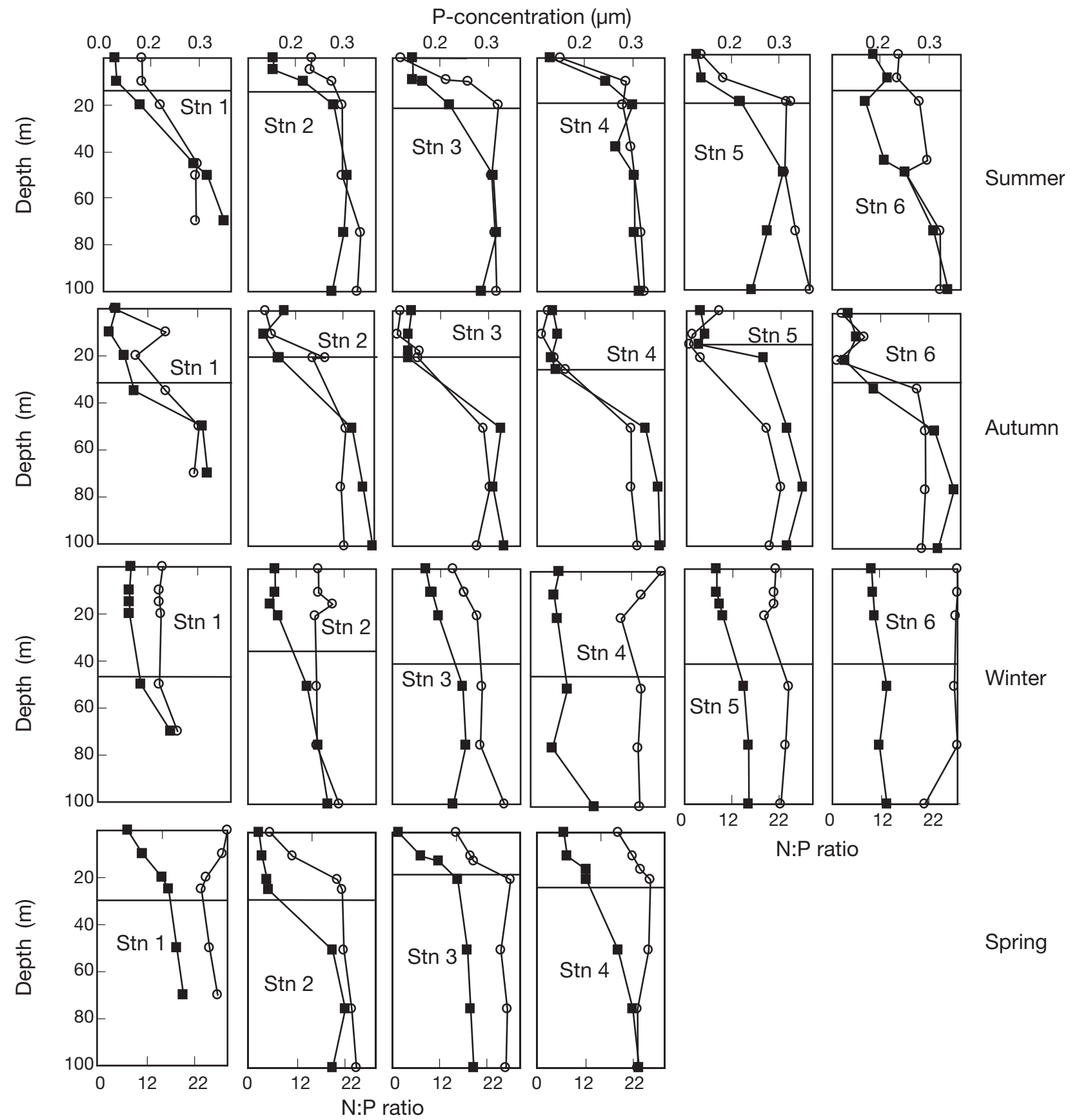

Fig. 4. Phosphate concentration $(\mathbb{\square})$ and N:P molar ratio (O) profiles at the sampling stations. Horizontal line indicates the lower limit position of the mixed layer

\section{Phytoplankton community structure at the surface and the sub-surface fluorescence maximum}

The micro-plankton size fraction accounted for $>50 \%$ of $\mathrm{chl}_{\mathrm{t}} \mathrm{a}$ in 29 out of the 44 samples analysed (Fig. 6). In contrast, pico-plankton contribution to $\mathrm{chl}_{\mathrm{t}}$ a was higher than the contribution of the micro- and nano-plankton in only 8 samples collected at the surface and 4 samples collected at the SFM depth. When all the stations were jointly compared, a vertical segregation of the $3 \mathrm{chl}$ a size fractions could be discerned, as the contribution of micro-plankton to $\mathrm{chl}_{\mathrm{t}} \mathrm{a}$ was significantly lower in the surface samples than in the SFM samples. However, the differences between surface and SFM samples were not statistically significant when the data from each particular survey were compared (Table 3), which can be attributed to high spatial variability. Nevertheless, there was a seasonal 


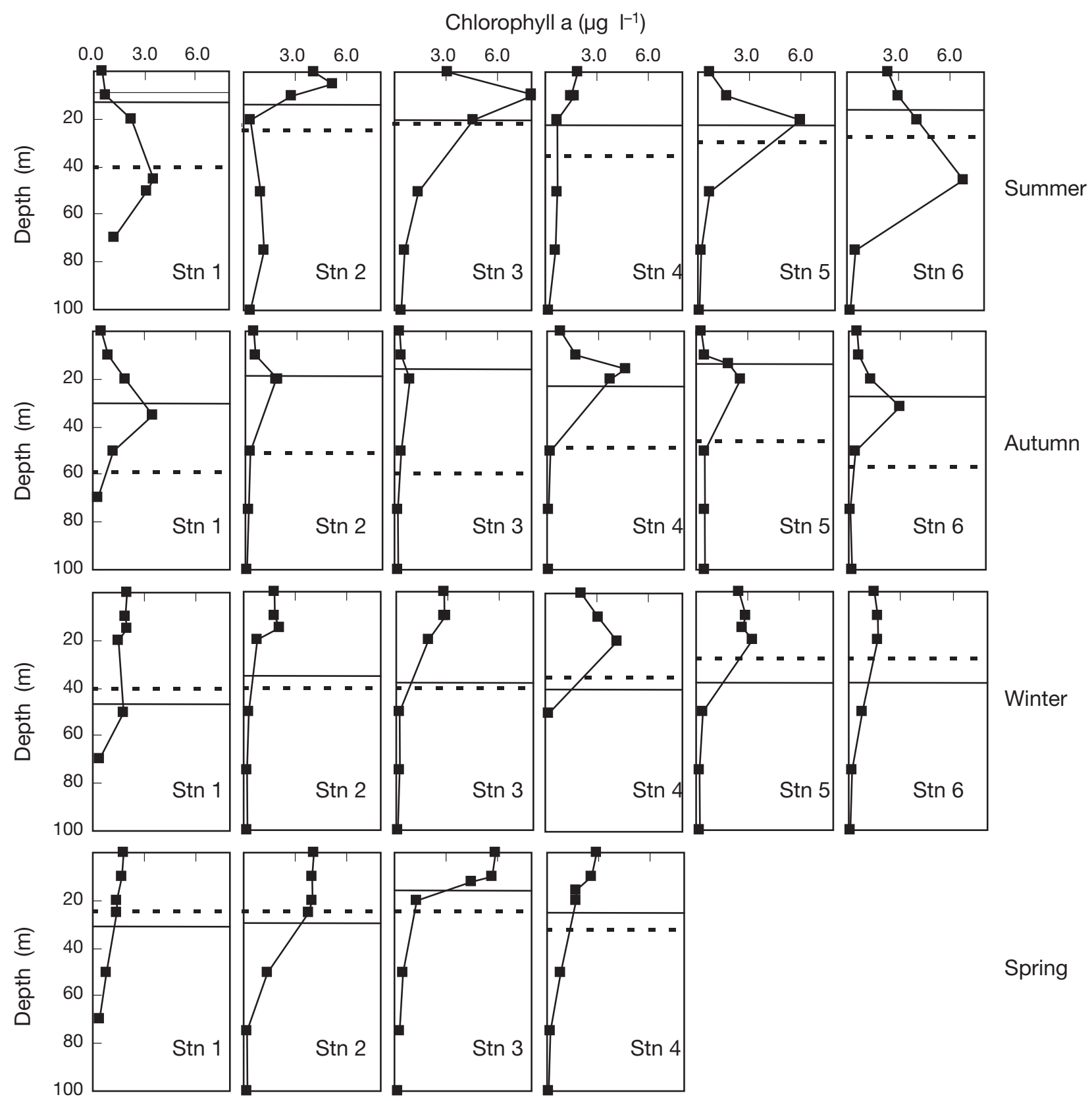

Fig. 5. Total chlorophyll a concentration profiles at the sampling stations. Continuous and dashed horizontal lines indicate the lower limit position of the mixed layer and the euphotic zone, respectively

variability pattern, as nano-plankton contribution to $\mathrm{chl}_{\mathrm{t}}$ a decreased in autumn and winter, while the contribution of pico-plankton increased in winter (Table 3).

Cell abundances of diatoms and dinoflagellates were analysed at the SFM samples (data for surface samples are not available). Seasonally, the higher abundances were obtained in summer (Table 3), due to the relatively high contribution of diatoms. Contrastingly, dinoflagellates dominated in autumn and winter. In spring, there were 2 samples (Stns 1 and 4) in which dinoflagellates were more abundant than diatoms. Globally, total and micro-plankton chl a concentrations were highly correlated with diatom abundance $(\mathrm{r}=0.96$ and 0.93 , respectively, $\mathrm{p}<0.001$, $\mathrm{n}=22$ ), while the correlations with dinoflagellates were not statistically significant $(r=0.10$ and 0.12 , respectively, $\mathrm{p}>0.05, \mathrm{n}=22$ ).

In order to determine the variables that could contribute to the variability of the chl a size structure in sur- 
(a)

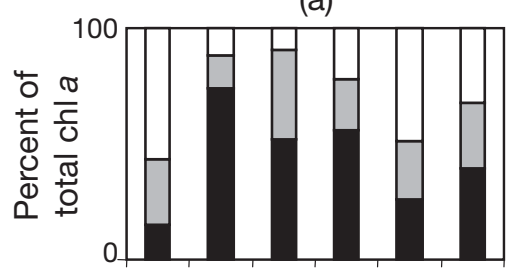

4
$\frac{0}{0} \frac{\pi}{\frac{1}{0}}$
$\frac{1}{0} \frac{0}{0}$
$\frac{0}{0} \frac{\pi}{0}$
0 $\frac{\pi}{\frac{\pi}{5}}$
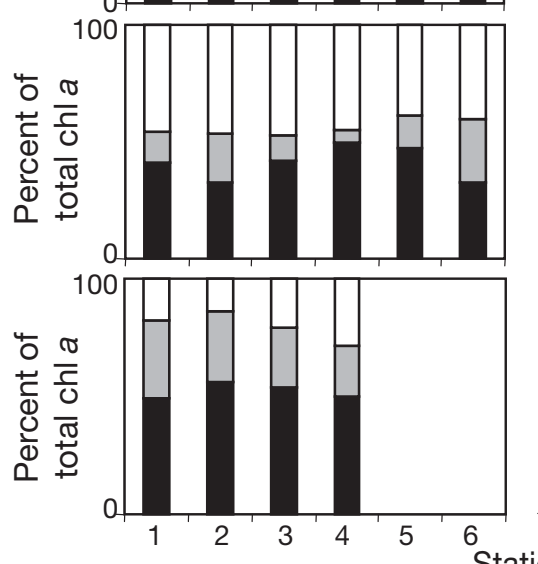

Station

Fig. 6. Relative contribution (\%) to the total chlorophyll $a$ of each size fraction (filled bars: micro-plankton; shaded bars: nano-plankton; open bars: pico-plankton) in (a) surface samples and (b) sub-surface fluorescence maximum samples (b)

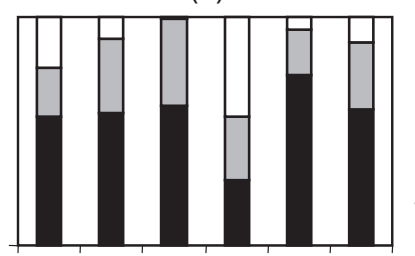

Summer

Autumn

Winter

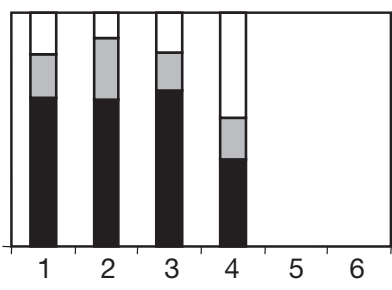

face samples, a PCA was performed (Fig. 7a,b). The winter samples were excluded from this analysis, as clear vertical gradients of nutrient concentration and phytoplankton community structure were not detected. Three principal components (PC) were extracted from the analysis, which explained 42,20 and $17 \%$ of the total variance, respectively. Factor loading plots for the first 2 PCs are shown in Fig. 7a. PC1 was negatively correlated with nutrient concentrations and positively with the AMI depth. Therefore, it could be understood as a hydrogeochemical component related to upwelling intensity and nutrient availability. Moreover, PC1 was positively correlated with picoplankton chl $a$, consequently indicating that the contribution of this size class to $\mathrm{chl}_{\mathrm{t}} \mathrm{a}$ was higher under nutrient limitation. PC2 was positively correlated with $\mathrm{chl}_{\mathrm{t}} a$ and microplankton chl $a$, and negatively with nano- and picoplankton chl $a$ and nutrient concentrations. It can be concluded that PC2 indicates changes in nutrient concentrations probably caused by their consumption by the phytoplankton, since this PC was not correlated

Table 3. Seasonal means $( \pm \mathrm{SD})$ of the particulate organic carbon $\left(\mathrm{POC}_{i} \mu \mathrm{mol} \mathrm{Cl^{-1 }}\right)$ and nitrogen $\left(\mathrm{PON} ; \mu_{m o l ~} \mathrm{l}^{-1}\right)$ concentrations, POC:total chl a $\left(\mu \mathrm{mol} \mathrm{C} \mathrm{gg}^{-1} \mathrm{chl}_{\mathrm{t}}\right.$ a) index, relative concentrations of the $3 \mathrm{chl}$ a (plankton) size fractions analysed for the surface and sub-surface chl a fluorescence maximum (SFM) samples. Seasonal means of the total cell, diatom and dinoflagellate abundances $\left(\right.$ cells $\mathrm{ml}^{-1}$ ) for SFM samples are also shown. For each row, significant differences among medians were tested at $\mathrm{p}<0.05$ with a Kruskal-Wallis $H$-test

\begin{tabular}{|c|c|c|c|c|c|}
\hline & Summer & Autumn & Winter & Spring & $\mathrm{p}$ \\
\hline \multicolumn{6}{|l|}{ Surface } \\
\hline POC & $15.6 \pm 3.7$ & $7.7 \pm 2.7$ & $8.2 \pm 1.6$ & $13.4 \pm 5.2$ & 0.03 \\
\hline PON & $1.5 \pm 0.4$ & $0.7 \pm 0.2$ & $1.1 \pm 0.3$ & $1.8 \pm 0.4$ & 0.02 \\
\hline POC: $\operatorname{chl}_{t} a$ & $6.6 \pm 3.7$ & $19.0 \pm 13.1$ & $4.2 \pm 0.6$ & $3.1 \pm 0.9$ & 0.01 \\
\hline Microplankton & $0.44 \pm 0.21$ & $0.40 \pm 0.19$ & $0.45 \pm 0.12$ & $0.52 \pm 0.04$ & 0.67 \\
\hline Nanoplankton & $0.26 \pm 0.08$ & $0.16 \pm 0.07$ & $0.15 \pm 0.08$ & $0.27 \pm 0.05$ & 0.02 \\
\hline Picoplankton & $0.30 \pm 0.19$ & $0.43 \pm 0.14$ & $0.40 \pm 0.09$ & $0.20 \pm 0.06$ & 0.11 \\
\hline \multicolumn{6}{|l|}{ SFM } \\
\hline POC & $11.6 \pm 3.7$ & $7.7 \pm 2.7$ & $8.2 \pm 1.6$ & $13.4 \pm 3.2$ & 0.22 \\
\hline PON & $1.9 \pm 0.9$ & $1.1 \pm 0.5$ & $1.1 \pm 0.3$ & $1.5 \pm 0.3$ & 0.14 \\
\hline POC:chl a & $2.5 \pm 0.4$ & $6.4 \pm 8.2$ & $3.2 \pm 0.8$ & $4.8 \pm 2.0$ & 0.19 \\
\hline Microplankton & $0.56 \pm 0.15$ & $0.51 \pm 0.20$ & $0.57 \pm 0.10$ & $0.58 \pm 0.14$ & 0.64 \\
\hline Nanoplankton & $0.28 \pm 0.07$ & $0.15 \pm 0.12$ & $0.10 \pm 0.06$ & $0.20 \pm 0.04$ & 0.01 \\
\hline Picoplankton & $0.15 \pm 0.15$ & $0.33 \pm 0.18$ & $0.34 \pm 0.12$ & $0.22 \pm 0.15$ & 0.06 \\
\hline \multicolumn{6}{|l|}{ Mean } \\
\hline Total cells & $554 \pm 339$ & $320 \pm 380$ & $306 \pm 175$ & $262 \pm 140$ & 0.13 \\
\hline Diatoms & $460 \pm 324$ & $146 \pm 143$ & $86 \pm 33$ & $142 \pm 116$ & 0.04 \\
\hline Dinoflagellates & $91 \pm 30$ & $174 \pm 242$ & $220 \pm 191$ & $120 \pm 133$ & 0.95 \\
\hline
\end{tabular}



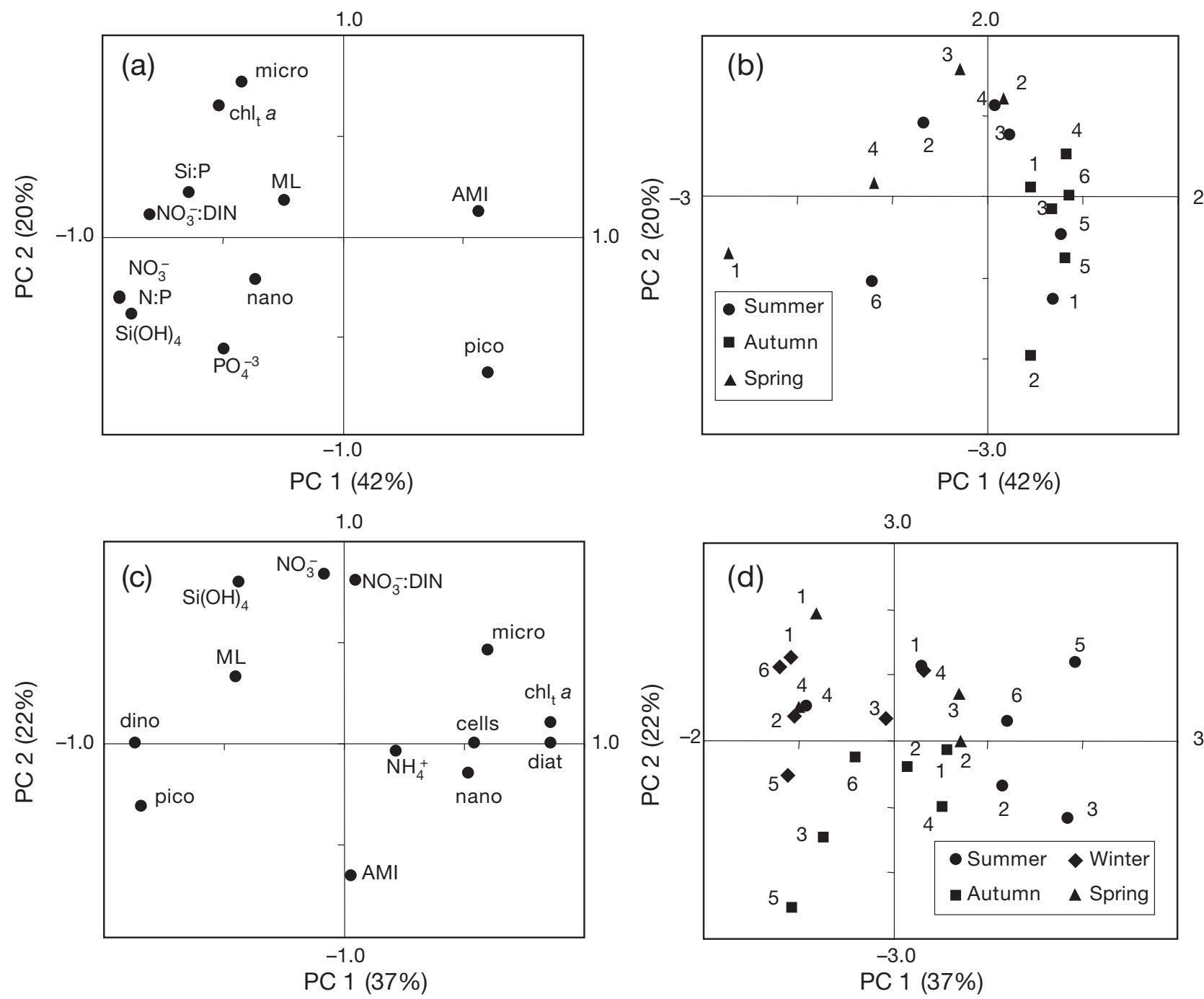

Fig. 7. Structure of the 2 first principal components (PC) and factor scores extracted from the principal component analysis (PCA) performed with the $(a, b)$ surface and $(c, d)$ sub-surface fluorescence maximum samples. Numbers in (b) and (d) indicate the corresponding station. ML: mixed layer depth; AMI: Atlantic-Mediterranean interface depth; $\mathrm{NO}_{3}{ }^{-}$:DIN: ratio of nitrate to total dissolved inorganic nitrogen; $\mathrm{N}$ :P: dissolved inorganic nitrogen to $\mathrm{PO}_{4}{ }^{3-}$ molar ratio; $\mathrm{Si}: \mathrm{P}: \mathrm{Si}(\mathrm{OH})_{4}$ to $\mathrm{PO}_{4}{ }^{3-} \mathrm{molar}$ ratio; $\mathrm{Si}(\mathrm{OH})_{4}$ : silicid acid; $\mathrm{NH}_{4}^{+}$: amonium; $\mathrm{chl}_{\mathrm{t}}$ a: total chlorophyll $a_{\text {; }}$ micro, nano and pico: relative contributions to the chl $a$ of micro-, nano-and pico-plankton, respectively; cells: micro-plankton cell abundance; diat and dino: diatom and dinoflagellate cell abundances, respectively

with the AMI depth. Thus, higher concentrations of $\mathrm{chl}_{\mathrm{t}}$ $a$ and micro-plankton chl $a$ could be related to a higher consumption of nitrate and phosphate. PC3 was positively correlated with microplankton chl $a$ and AMI depth, and negatively with nanoplankton chl $a$. Therefore, this PC indicates the relative importance of nanoplankton with respect to the microplankton size fraction. There was no homogeneous score pattern in PC1 and PC2 for the summer samples (Fig. 7b), as Stns 3 and 4 had positive scores in both PCs, while scores for Stn 6 were negative. These results are indicative of high spatial variability in both hydrology and phytoplankton community structure, as commented on above. All the autumn samples exhibited positive scores for PC1, showing that they were characterized by lower nutrient concentrations and a dominance of picoplankton. The highest PC1 score was obtained at Stn 1 in spring, due to its high nutrient concentration. It is interesting to note that this relatively high nutrient concentration in spring did not lead to clear dominance of the microplankton chl $a$ fraction, as the scores in PC2 of Stns 1 and 4 were very low. Contrastingly, PC2 scores for Stns 2 and 3 in spring were positive, showing that the micro-plankton size class dominated the community. The scores in PC3 for the different samples did not show any remarkable seasonal variability pattern (data not shown). 
The results of the PCA for the SFM samples are shown in Fig. $7 \mathrm{c}$, d. The first 3 PCs explained 37,22 and $12 \%$ of the total variance. PC1 was positively correlated to abundance of diatoms and micro-plankton chl $a$, and negatively to dinoflagellate abundance and picoplankton chl $a$. Therefore, this PC can be interpreted as a phytoplanktonic component. PC2 was positively correlated to nutrient concentration, and negatively to AMI depth; therefore, it is a hydrogeochemical axis. On average, the summer samples had positive scores in PC1 (Fig. $7 d_{\text {; }}$ with the exception of Stn 4), but scores in PC2 were non-homogeneous, indicating that the changes in the phytoplankton community structure were poorly related to hydrology and nutrients. In autumn, PC1 scores were positive for Stns 1, 2 and 4, which also had low PC2 scores. However, both PC1 and PC2 scores for Stns 3 and 5 were negative, indicating that the higher relative importance of picoplankton in these samples was linked to low nutrient availability. On average, the PC1 scores were negative and the PC2 scores were positive for the winter samples, indicating that nutrient availability was higher in winter than in autumn, although it was not accompanied by an increase in the diatom abundance or microplankton $\mathrm{chl}$ a standing stock. A similar conclusion can be drawn for Stns 1 (with the highest PC2 score obtained) and 2 in spring.

\section{Nitrogen uptake and its relationship with nutrients and phytoplankton community structure}

The absolute $\mathrm{NO}_{3}^{-}$uptake rates $\left(\mathrm{NNO}_{3}{ }^{-}\right)$were highly variable, as they ranged from 270 to $<0.1 \mathrm{nmol} \mathrm{N} \mathrm{l}^{-1} \mathrm{~h}^{-1}$ (Fig. 8). On average, $\rho \mathrm{NO}_{3}{ }^{-}$was higher in summer (Table 4), although the seasonal means were not statistically significant due to the high spatial variability. The variation range for $\mathrm{NH}_{4}{ }^{+}$ absolute uptake rates $\left(\mathrm{\rho NH}_{4}{ }^{+}\right)$was similar (from 230 to $0.8 \mathrm{nmol} \mathrm{N}^{-1} \mathrm{~h}^{-1}$ ). Urea uptake was detected only in 10 samples. In general, it represented $<5 \%$ of the total N-uptake rates.

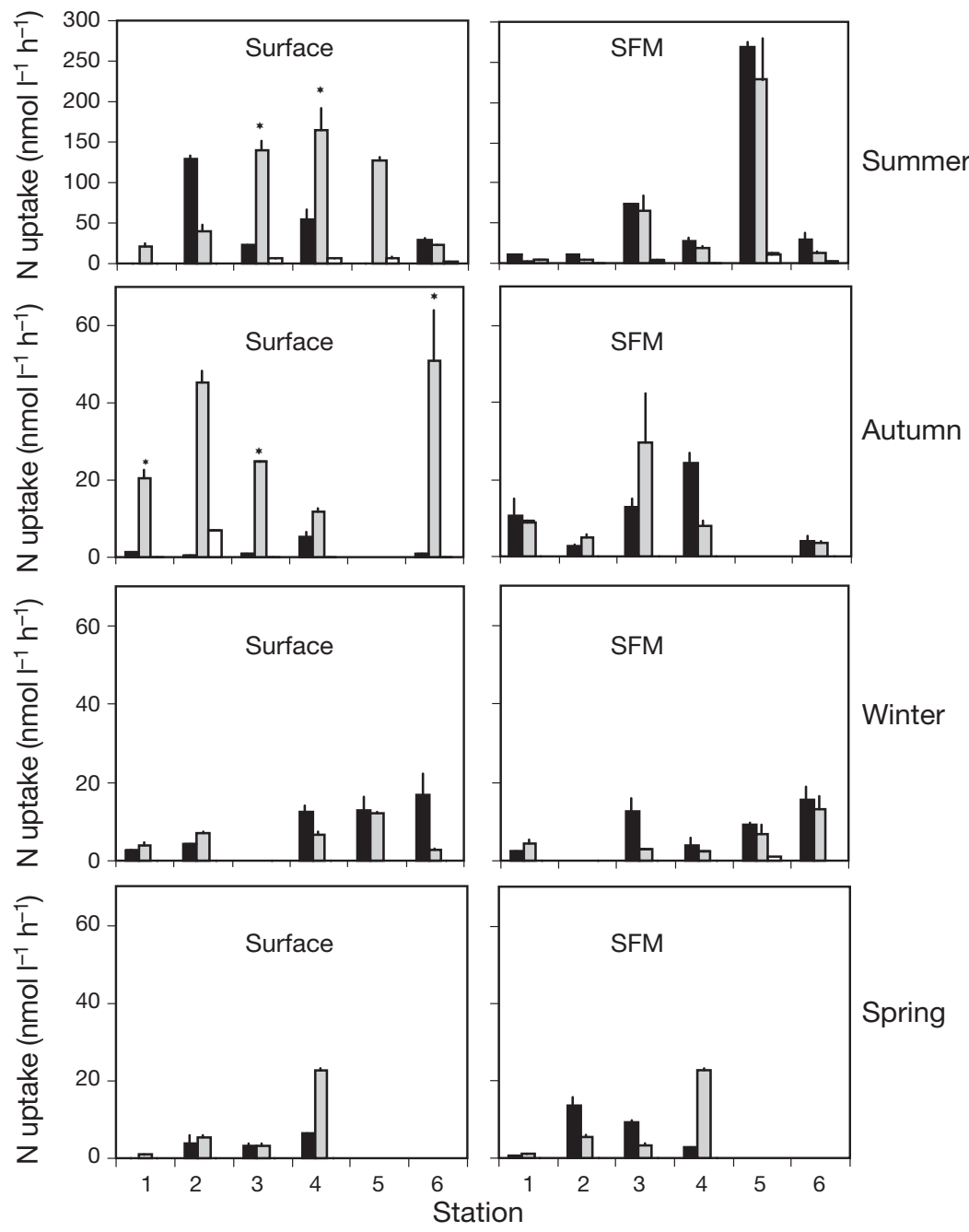

Fig. 8. Absolute uptake rates (+SD) of $\mathrm{NO}_{3}{ }^{-}$(filled bars), $\mathrm{NH}_{4}{ }^{+}$(shaded bars) and urea (open bars) for the surface and sub-surface chlorophyll a fluorescence maximum (SFM) samples. $\mathrm{NH}_{4}^{+}$uptake rates marked with asterisks could be underestimated by $>5 \%$ due to the dilution effect (see 'Materials and methods'). Note that the urea uptake was not measurable in many samples and SD for some measurements was low (not visible)

Table 4. Seasonal means $( \pm \mathrm{SD})$ of the absolute uptake rates of $\mathrm{NO}_{3}^{-}\left(\mathrm{\rho NO}_{3}{ }^{-}\right.$, nmol $\left.\mathrm{N} \mathrm{l}^{-1} \mathrm{~h}^{-1}\right)$ and $\mathrm{NH}_{4}{ }^{+}\left(\mathrm{NNH}_{4}{ }^{+}, \mathrm{nmol} \mathrm{N} \mathrm{l^{-1 }} \mathrm{h}^{-1}\right), \mathrm{N}$-specific $\mathrm{NO}_{3}{ }^{-}$uptake rates $\left(\mathrm{VNO}_{3}{ }^{-}, \mathrm{h}^{-1}\right)$ and relative $\mathrm{NO}_{3}^{-}$uptake rate $\left(\mathrm{rNO}_{3}^{-}\right)$for the surface and chlorophyll a fluorescence maximum (SFM) samples. For each row, significant differences among medians were tested at $\mathrm{p}<0.05$ with a Kruskal-Wallis $H$-test

\begin{tabular}{|cccccc|}
\hline & Summer & Autumn & Winter & Spring & $\mathrm{p}$ \\
\hline Surface & & & & & \\
$\mathrm{\rho NO}_{3}{ }^{-}$ & $39.3 \pm 48.7$ & $1.7 \pm 2.1$ & $10.3 \pm 5.7$ & $3.4 \pm 2.6$ & 0.13 \\
$\mathrm{\rho NH}_{4}{ }^{+}$ & $86.2 \pm 65.2$ & $30.6 \pm 16.6$ & $6.4 \pm 3.6$ & $11.4 \pm 4.7$ & 0.004 \\
$\mathrm{VNO}_{3}{ }^{-}$ & $0.02 \pm 0.02$ & $0.003 \pm 0.01$ & $0.01 \pm 0.01$ & $0.002 \pm 0.002$ & 0.16 \\
$\mathrm{rNO}_{3}{ }^{-}$ & $0.28 \pm 0.30$ & $0.09 \pm 0.13$ & $0.57 \pm 0.23$ & $0.24 \pm 0.17$ & 0.07 \\
$\mathrm{SFM}^{-}$ & & & & & \\
$\mathrm{\rho NO}_{3}{ }^{-}$ & $69.9 \pm 100.4$ & $10.9 \pm 8.6$ & $8.7 \pm 5.6$ & $6.4 \pm 5.9$ & 0.11 \\
$\mathrm{\rho NH}_{4}{ }^{+}$ & $55.5 \pm 88.3$ & $10.8 \pm 10.7$ & $5.3 \pm 4.1$ & $8.2 \pm 9.9$ & 0.38 \\
$\mathrm{VNO}_{3}{ }^{-}$ & $0.03 \pm 0.03$ & $0.01 \pm 0.005$ & $0.01 \pm 0.01$ & $0.003 \pm 0.002$ & 0.08 \\
$\mathrm{rNO}_{3}{ }^{-}$ & $0.62 \pm 0.08$ & $0.50 \pm 0.17$ & $0.57 \pm 0.19$ & $0.48 \pm 0.30$ & 0.59 \\
\hline
\end{tabular}


In the surface samples, the correlation between $\mathrm{NOO}_{3}{ }^{-}$and $\rho \mathrm{NH}_{4}{ }^{+}$was not statistically significant $(\mathrm{r}=0.28, \mathrm{p}>0.05, \mathrm{n}=20)$. N-uptake rates were not significantly correlated with $\mathrm{chl}_{\mathrm{t}} \mathrm{a}(\mathrm{r}=0.37, \mathrm{p}=0.11$, $\mathrm{n}=20$ and $\mathrm{r}=0.02, \mathrm{p}=0.93, \mathrm{n}=20$ for $\mathrm{\rho NO}_{3}{ }^{-}$and $\mathrm{\rho NH}_{4}{ }^{+}$, respectively) or nutrient concentration. However, $\mathrm{PNO}_{3}^{-}$was correlated (although weakly) with microplankton chl a concentration $(\mathrm{r}=0.56, \mathrm{p}<0.05, \mathrm{n}$ $=20$ ). On the contrary, the correlations between $\mathrm{chl}_{\mathrm{t}} \mathrm{a}$ and $\rho \mathrm{NO}_{3}{ }^{-}$and $\rho \mathrm{NH}_{4}{ }^{+}$were statistically significant and positive in the SFM samples $(r=0.83$ and 0.78 , respectively, $\mathrm{p}<0.01, \mathrm{n}=20$ ). $\mathrm{\rho NO}_{3}{ }^{-}$and $\mathrm{\rho NH}_{4}{ }^{+}$were also positively correlated to diatom abundance ( $\mathrm{r}=0.66$ and $\mathrm{r}=0.82$, respectively, $\mathrm{p}<0.01, \mathrm{n}=20$ ) at the SFM. However, the $\mathrm{N}$-uptake rates were not significantly correlated to the size-fractioned chl a concentrations or nutrient concentrations. The $\mathrm{N}$-specific $\mathrm{NO}_{3}{ }^{-}$uptake rates (i.e. $\mathrm{\rho NO}_{3}{ }^{-}$normalized by $\mathrm{PON}$, termed $\mathrm{VNO}_{3}{ }^{-}$) appeared to vary seasonally, as very low values were obtained in the surface samples during autumn and spring and in the SFM samples in spring (Table 4).

The relative nitrate uptake in the study area ranged from 0.01 to 0.86 . During summer, autumn and spring, the lower values of relative nitrate uptake were obtained in the surface samples, while it usually increased in the SFM samples (with the exception of Stn 4 in spring; Table 4, Fig. 9). Values much $<0.1$ were obtained in the surface samples at Stns 1 and 5 in summer and at Stn 2 in autumn. In winter, the relative nitrate uptake in the surface samples was not significantly different with that in the SFM samples. Seasonally, the relative nitrate uptake in the surface samples was lower in autumn (Table 4). For these samples, there was a positive relationship between $\mathrm{pNO}_{3}{ }^{-}$ and relative $\mathrm{NO}_{3}{ }^{-}$uptake $(\mathrm{r}=0.75, \mathrm{p}<0.01, \mathrm{n}=19$ ), while relative $\mathrm{NO}_{3}{ }^{-}$uptake varied irrespective of the changes in $\mathrm{\rho NH}_{4}{ }^{+}$. Therefore, the changes in relative $\mathrm{NO}_{3}{ }^{-}$uptake led to higher $\mathrm{\rho NO}_{3}{ }^{-}$at this depth. In contrast, the correlations between relative $\mathrm{NO}_{3}{ }^{-}$uptake and $\rho \mathrm{NO}_{3}{ }^{-}$or $\rho \mathrm{NH}_{4}{ }^{+}$were not statistically significant ( $r=0.07$ and 0.08 , respectively, $\mathrm{p}>0.05, \mathrm{n}=19$ ) in the SFM samples.

In order to discern which factor (nutrient concentration or phytoplankton community structure) had a greater importance in determining the relative nitrate uptake values, the relationship between the PC scores extracted from the PCA and the relative nitrate uptake values for each station were compared (Fig. 10; note that the winter surface samples were not used for this comparison). In the surface, there was a weak negative correlation between $\mathrm{PC} 1$ scores and the relative nitrate uptake $(\mathrm{r}=-0.25, \mathrm{p}<0.05, \mathrm{n}=15)$. Note that Stn 1 in spring (lower left data point in Fig. 10a) departs considerably from this relationship. If this sample is excluded from the analysis, the PC1 score changes
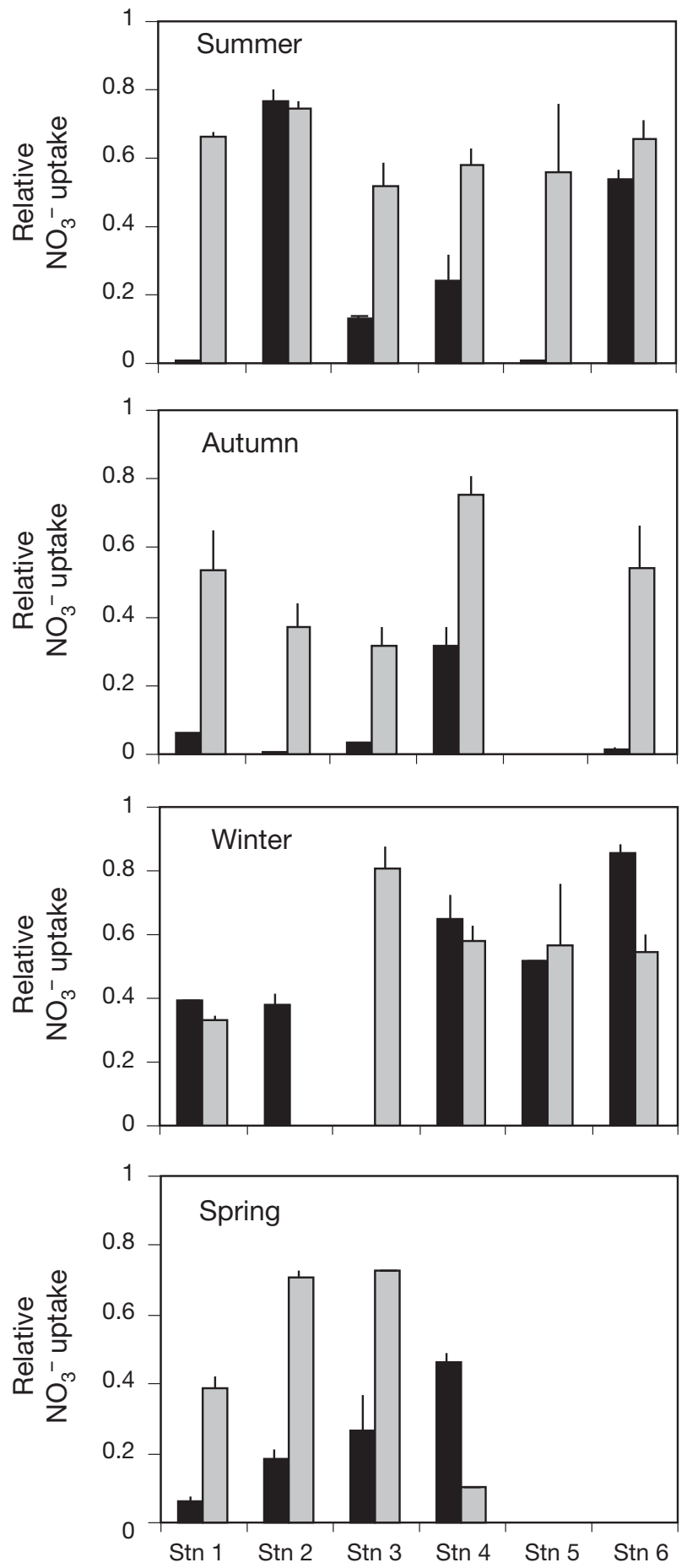

Fig. 9. Relative uptake $(+\mathrm{SD})$ of $\mathrm{NO}_{3}{ }^{-}$in the surface (filled bars) and the sub-surface chl a fluorescence maximum (shaded bars) samples and SD for some measurements was low (not visible)

explain about $60 \%$ of the relative nitrate uptake variability ( $\mathrm{r}=-0.76, \mathrm{p}<0.01, \mathrm{n}=14$ ). The correlation between the relative nitrate uptake and PC2 scores was not statistically significant. These results indicate that relative nitrate uptake in the surface was con- 

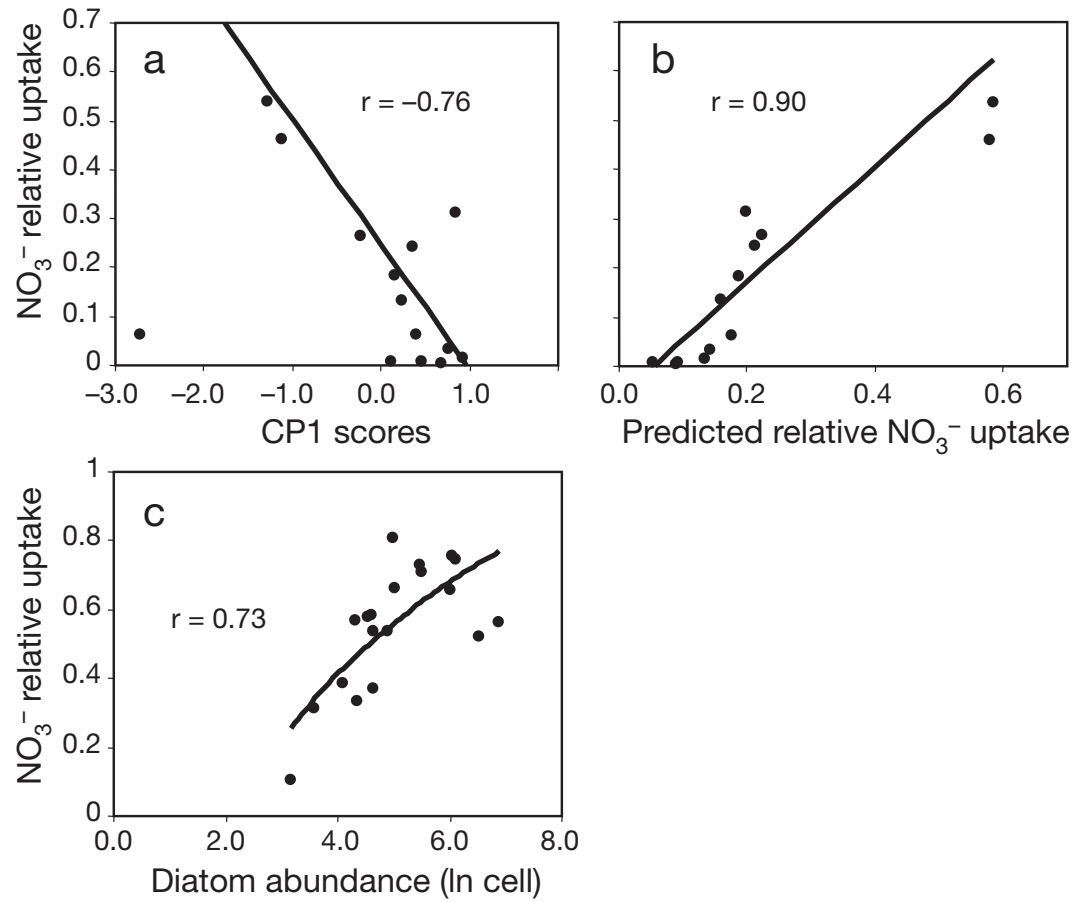

Fig. 10. Relationship between the relative $\mathrm{NO}_{3}{ }^{-}$uptake and the first principal component (PC1) scores extracted from the PCA for (a) surface samples and (b) measured versus predicted relative $\mathrm{NO}_{3}{ }^{-}$uptake according to the multiple regression model calculated among $\mathrm{NO}_{3}{ }^{-}$relative uptake (dependent variable) and micro-plankton chlorophyll a concentrations. (c) Relationship between $\mathrm{NO}_{3}{ }^{-}$ relative uptake and diatom cell abundance (logarithmic scale) in the sub-surface fluorescence maximum samples

trolled mainly by hydrology and nutrient availability, since the PC1 was considered a hydro-geochemical axis. Nevertheless, the relative nitrate uptake could be influenced by the size structure of the phytoplankton community, as correlation between the contribution of the micro-plankton to the total chl $a$ and the relative nitrate uptake was obtained $(\mathrm{r}=0.57, \mathrm{p}<0.05, \mathrm{n}=14)$. In fact, a multiple regression analysis performed with nitrate concentration and micro-plankton contribution to $\mathrm{chl} a$ as the independent variables and the relative nitrate uptake as the dependent one (excluding the sample obtained at Stn 1 in spring) produced a model which explained about $81 \%$ of the variability of the relative nitrate uptake ( $\mathrm{r}=0.90, \mathrm{p}<0.001$; Fig. 10b). In the SFM samples, the relative nitrate uptake was correlated significantly with the PC1 scores $(\mathrm{r}=0.51, \mathrm{p}=$ $0.04, \mathrm{n}=17$ ), but the correlation with the PC2 scores was not significant. This indicates that the changes in relative nitrate uptake were mainly driven by the variability in phytoplankton composition. In fact, there was a positive relationship between abundance of diatoms and relative nitrate uptake $(\mathrm{r}=0.73, \mathrm{p}<0.001, \mathrm{n}=19$; Fig. 10c). On the contrary, the correlations between relative nitrate uptake and dinoflagellate abundance or nitrate concentration were not significant.

\section{DISCUSSION}

\section{Hydrographic variability and its effects on nutrients and phytoplankton community}

The seasonal hydrographic cycle in the study area was characterized by (1) the changes in the SAW layer thickness, which seemed to be more or less modified (as estimated from the deviations of surface salinity with respect to the salinity of SAW) depending on the vertical position of the AMI. Thus, SS in autumn was close to that expected for slightly modified SAW, coinciding with a deeper AMI. On the other hand, the highest SS was observed in spring, when AMI was shallower. (2) The presence of a ML was found, which was relatively shallow from spring to autumn. This seasonal cycle resembles the one described previously by Ramírez et al. (2006) and Mercado et al. (2007) for the northwest Alboran Sea. In spite of this, the spatial variability of the ML and the SAW layer thickness was prominent, especially in summer. High spatial variability has also been described previously for the study area, as a consequence of the mesoscale and sub-mesoscale structures fuelled by SAW inflow (Cheney \& Doblar 1982, Parrilla \& Kinder 1987, Tintoré et al. 1991) and/or changes in the wind regime (Cano \& Lafuente 1991, Agostini \& Bakun 2002). Additionally, the incursion of small cores of North Atlantic Central Water (NACW), characterized by very low salinity in comparison to SAW, could contribute to the hydrological variability in summer, as very low SS was obtained at Stns 4 and 6. The presence of this water mass in the study area has been previously demonstrated by Ramírez et al. (2005).

On average, nutrient concentrations showed a strong vertical gradient, the nutricline being located close to the lower limit of the mixed layer in summer, autumn and spring. Under these conditions, nutrients (mainly $\mathrm{NO}_{3}{ }^{-}$) were often exhausted in the surface layer unless an AMI raising occurred (i.e. an intensification of the LIW upwelling as observed at Stns 1 and 4 in spring). In fact, according to the results of the PCA performed with the surface samples, the nutrient concentration in this layer was correlated with the vertical position of AMI. Another possible fertilization mechanism of the surface layer was the mentioned presence of NACW cores in summer, since this water mass is characterized by nutrient concentration higher than the SAW (Ramírez et al. 2005). 
The water column stratification could enhance the formation of the prominent SFM, which was usually located close to the lower limit of the mixed and nutrient-depleted layer (when present). At this depth, the occurrence of photo-acclimation could be expected as light-limitation conditions could have occurred. In contrast, nutrient limitation of phytoplankton growth could have occurred in the surface samples (especially in autumn). Consequently, physiological and taxonomic differences between the phytoplankton communities growing in the surface layer and those growing at SFM depth could have occurred. Concordantly, the POC: chl $_{\mathrm{t}}$ a ratio (which has been used as a photoacclimation index, see e.g. Neveux et al. 2003) increased, on average, in the surface samples (228 \pm

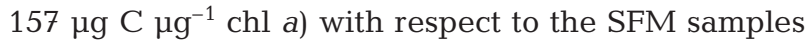
$\left(49 \pm 50 \mu \mathrm{g} \mathrm{C} \mathrm{\mu g}^{-1} \mathrm{chl} \mathrm{a}\right)$, which could indicate a lower chl a cell content in the surface samples. The POC: $\mathrm{chl}_{\mathrm{t}}$ a ratio increases are compatible with the expected response of phytoplankton to $\mathrm{NO}_{3}{ }^{-}$limitation (Stramski et al. 2002). On the contrary, numerous laboratory studies reveal that phytoplankton acclimation to a low light environment produces increases of chl a content per cell (Berner et al. 1989, Stramski et al. 2002), i.e. lower ratios of POC to $\mathrm{chl}_{\mathrm{t}} \mathrm{a}$. Similar acclimation responses by phytoplankton assemblages in the Alboran Sea have been described previously (Mercado et al. 2006, 2007). Modifications in the size structure of the communities could also contribute to changes in the POC: $\mathrm{chl}_{\mathrm{t}}$ a ratio, since, on average, contribution of the microplankton to $\mathrm{Chl}_{\mathrm{t}}$ a was higher in the SFM samples than in the surface samples during stratification, while the pico-phytoplankton size fraction chl a was higher in the surface samples. This vertical distribution pattern is in agreement with the one reported by Bautista \& Jiménez-Gómez (1996) and Mercado et al. (2006) for the Alboran Sea. However, this pattern was not obtained at some stations where the contribution of micro-plankton to the total chl a was even higher in the surface than in the SFM samples. This variability in the contribution of each size class to the total chl a was related to the spatial hydrographic variability and the consequent local injection of new $\mathrm{NO}_{3}{ }^{-}$into the surface layer, as shown by the PCA performed with the surface samples. According to this analysis, the contribution of the pico-plankton to total chl a was positively correlated with the AMI depth, indicating that this size fraction tended to dominate the community when the thickness of the modified SAW layer (poor in nutrient) was larger (i.e. under nutrient starvation conditions). These conclusions are in agreement with the widely accepted paradigm that small cells dominate the community when nutrients are impoverished, while the injection of nutrients into the euphotic zone by different processes of mesoscale phenomena favour the growth of large phytoplankton cells (Goldman 1993). However, it has to be noted that the relatively high nitrogen availability in the form of $\mathrm{NO}_{3}{ }^{-}$and $\mathrm{NH}_{4}{ }^{+}$in the surface sample at Stn 1 in spring did not match with a high dominance of the micro-plankton (as estimated from its contribution to $\mathrm{chl}_{\mathrm{t}}$ a) or a high $\mathrm{chl}_{\mathrm{t}} \mathrm{a}$ concentration. Similarly, diatom abundance (which was the main group contributing to the micro-plankton and the $\operatorname{chl}_{\mathrm{t}} a$ ) in the SFM samples at this station was low (in fact, these samples had the lowest abundance of all the ones analysed). High nutrients and low chl a have been described in some coastal systems during early stages of the phytoplankton bloom following upwelling induced by winds (Dugdale et al. 2006), as there is a time lag between $\mathrm{NO}_{3}{ }^{-}$enrichment and the phytoplankton growth response. This acclimation cycle is characterized by low $\mathrm{N}$-specific $\mathrm{NO}_{3}{ }^{-}$uptake rates ( $\mathrm{VNO}_{3}^{-}$; Dugdale et al. 2006). In our experiments, the low diatom abundance at Stn 1 in spring coincided with very low $\mathrm{\rho NO}_{3}{ }^{-}$and $\mathrm{VNO}_{3}{ }^{-}$values (in fact, they were the lowest values measured); therefore, it can be postulated that the community was sampled during the adaptation phase. Nevertheless, the $\mathrm{PO}_{4}{ }^{3-}$ concentration was very low and the N:P molar ratio was higher than the Redfield ratio at this station. This fact could affect the response of the phytoplankton to $\mathrm{NO}_{3}{ }^{-}$ enrichment.

\section{Reliability of the ${ }^{15} \mathrm{~N}$ technique in the study area}

The determination of in situ $\mathrm{N}$-uptake rates from ${ }^{15} \mathrm{~N}$ enrichment experiments has a number of methodological problems the effect of which varies depending on the characteristics of the samples and the experimental procedure (Dugdale \& Wilkerson 1986). One possible error source is the decline of $\mathrm{N}$ uptake during incubations, as described by Glibert \& Goldman (1981). $\mathrm{N}$-uptake time-course experiments performed with samples from the study area did not indicate a decline of $\mathrm{N}$ uptake during the first 2 to $3 \mathrm{~h}$ of incubation (data not shown). Therefore, the incubation time adopted in our experiment ( 2 to $4 \mathrm{~h}$ ) must minimise this error. Another potential problem is the production of the reduced- $\mathrm{N}$ form due to regeneration that creates dilution of the isotope concentration during incubation. It could lead to the underestimation of $\mathrm{NH}_{4}{ }^{+}$and urea uptake rates. According to Kanda et al. (1987), the dilution effect increases with longer incubation periods, larger uptake fluxes and smaller substrate concentrations. The short incubation time period adopted in our experiments should reduce the dilution effect. Besides, the urea uptake rates were very low; therefore, the effect of dilution should not be very high. However, there were important differences in $\mathrm{NH}_{4}{ }^{+}$ 
uptake rates and concentrations among the different samples. If it is assumed that uptake and regeneration rates are tightly coupled and that PON concentration does not change substantially during the incubation period (see 'Materials and methods'), the underestimation of $\mathrm{\rho NH}_{4}{ }^{+}$could be calculated using Eq. (8) in Kanda et al. (1987). According to the results of these calculations, this underestimation was $<5 \%$ in most of the samples. Isotope dilution could significantly affect (by about $40 \%$ ) the $\mathrm{NH}_{4}{ }^{+}$uptake rates in only 2 experiments performed in summer with SFM samples collected at Stns 3 and 5, and in autumn with surface samples collected at Stns 1, 3 and 6. The high predicted dilution effect for these samples was mainly due to the high $\mathrm{NH}_{4}{ }^{+}$uptake values. In any case, it has to be noted that the impact of the dilution effect on relative $\mathrm{NO}_{3}{ }^{-}$uptake was very low in autumn, as $\mathrm{\rho NO}_{3}{ }^{-}$was also very low.

\section{Nitrogen uptake and phytoplankton community structure}

The changes in the phytoplankton community structure should affect its $\mathrm{N}$-uptake rates as a functional relationship between phytoplankton size structure and new production has been proposed (Tremblay et al. 1997). Accordingly, when the whole pool of data is compared, there was a statistically significant correlation between the micro-plankton chl a concentration and $\mathrm{\rho NO}_{3}^{-}(\mathrm{r}=0.79, \mathrm{p}<0.01, \mathrm{n}=44)$ and $\rho \mathrm{NH}_{4}{ }^{+}$ $(\mathrm{r}=0.44, \mathrm{p}<0.05, \mathrm{n}=44)$. The correlation between pico-plankton chl $a$ and $\mathrm{\rho NO}_{3}{ }^{-}$or $\mathrm{\rho NH}_{4}{ }^{+}$was not statistically significant. This result indicates that the differences in $\mathrm{N}$ uptake among the analysed samples were mainly due to variations in the micro-plankton. As postulated by Dugdale \& Wilkerson (1991), high N-uptake rates require either high phytoplankton biomass and/or high $\mathrm{N}$-specific $\mathrm{N}$ uptake. In our system, the increase of $\mathrm{\rho NO}_{3}{ }^{-}$and $\rho \mathrm{NH}_{4}{ }^{+}$was effectively linked to higher $\mathrm{chl}_{\mathrm{t}}$ a concentrations. However, $\mathrm{VNO}_{3}{ }^{-}$was also correlated with micro-plankton chl a concentration ( $\mathrm{r}=$ 0.59, $\mathrm{p}<0.01, \mathrm{n}=44$ ), but not with $\mathrm{VNH}_{4}{ }^{+}$, suggesting that the higher rates of $\mathrm{N}$ uptake in the assemblages dominated by micro-plankton were due to both a higher biomass and an increase of the specific $\mathrm{NO}_{3}{ }^{-}$ uptake. This could explain the higher values of relative $\mathrm{NO}_{3}{ }^{-}$uptake obtained in the SFM samples in comparison to the surface samples during the stratification period. This conclusion is also strongly supported by the good correlation obtained between $\mathrm{VNO}_{3}{ }^{-}$and relative $\mathrm{NO}_{3}{ }^{-}$uptake and abundance of diatoms among the SFM samples (note that data of diatom abundance are not available for the surface samples). Interestingly, at this depth level, the relative $\mathrm{NO}_{3}{ }^{-}$uptake was apparently independent of the $\mathrm{NO}_{3}{ }^{-}$concentration. It follows that changes in the phytoplankton community structure produced variability in relative nitrate uptake in spite of the $\mathrm{NO}_{3}{ }^{-}$concentration. This conclusion is consistent with the results of Probyn (1988), Glibert et al. (1991) and Dauchez et al. (1996), who reported that $f$-ratio and ambient nitrate were not correlated.

By contrast, the positive relationship between the micro-plankton chl a size fraction and the relative nitrate uptake is very weak $(\mathrm{r}=0.58, \mathrm{p}<0.05, \mathrm{n}=14)$ when only the surface samples are considered, indicating that the influence of the phytoplankton community size structure on relative nitrate uptake was low at this depth. In fact, the relative nitrate uptake was high even in phytoplankton assemblages dominated by pico-plankton (e.g. Stn 6 in summer). At this depth, the $\mathrm{NO}_{3}{ }^{-}$concentration changes explained about $73 \%$ of the relative nitrate uptake variability. This indicates that large- and small-sized phytoplankton were able to use both regenerated and new nitrogen sources as demonstrated by Furnas (1983).

On average, the values of $\mathrm{\rho NO}_{3}{ }^{-}$and $\rho \mathrm{NH}_{4}{ }^{+}$obtained in this paper are within the range published for different upwelling systems (MacIsaac et al. 1985, Dugdale \& Wilkerson 1991, Raimbault et al. 2000). These averaged uptake rates do not adequately characterize the study area, since the N-uptake variability was very high. The lower values are similar to the ones described for oceanic areas of limited productivity like oligotrophic and high-nutrient, low-chlorophyll (HNLC) regions (Dugdale \& Wilkerson 1991). The variation range in relative $\mathrm{NO}_{3}{ }^{-}$uptake was also remarkable. The vertical structure of the water column accounted for a great part of this variability. However, the variation range was also remarkable when the averaged values for the euphotic zone (i.e. the ones calculated as the mean between the surface and SFM samples at each station, which can be considered an estimation of the new relative to total production or $f$-ratio) are considered (from 0.2 to 0.9 ). The higher $f$-ratios compare well with the values reported by Owens et al. (1993) for Indian Ocean coastal regions and with those found by Dugdale et al. (2006) for some phases of the coastal phytoplankton bloom induced by an upwelling plume in California. A similar variation range in $f$-ratios has been described by Dauchez et al. (1996) for the Scotia Shelf during an annual cycle. The time variability in the $f$-ratio has not been studied previously in the Alboran Sea; however, L' Helguen et al. (2002) reported $f$ ratio values ranging from 0.11 to 0.37 for areas of contrasting productivity in this basin. In spite of the spatial differences, our data potentially indicate important seasonal differences in the $f$-ratio within the euphotic zone, which were related to the seasonal hydrological 
cycle. In winter, new production exceeded regenerated production (the $f$-ratio was 0.59 ). In summer, the new production was apparently compensated for by the regenerated production (the $f$-ratio mean was 0.45), but, in autumn and spring, new production was consistently lower than regenerated production (the $f$ ratio was 0.29 and 0.36 , for autumn and spring, respectively). On an annual scale, the $f$-ratio averaged 0.42 , which indicates a slightly higher contribution of regenerated production to total production.

In conclusion, we can surmise the following: (1) the expected relationship between relative nitrate uptake and the $\mathrm{NO}_{3}{ }^{-}$concentration is obtained where and when limitation occurs, (2) the proposed relationship between relative nitrate uptake and large phytoplankton mainly operates at non-limiting nitrate concentrations (i.e. in the SFM samples) and (3) diatoms are the main taxonomic group supporting the new production in this study area of the Alboran Sea.

Acknowledgements. We thank the crew of the RV 'Odón de Buen' for their invaluable help at sea. This work has been funded by the Projects ECOMÁLAGA (Instituto Español de Oceanografía, IEO), NORALBORÁN (REN2002-04022-CO2MAR, Ministerio Español de Educación y Ciencia, MEC) and NITROALBORAN (CTM2006-00426, MEC), co-financed from FEDER-EU.

\section{LITERATURE CITED}

Agostini VN, Bakun A (2002) 'Ocean triads' in the Mediterranean Sea: physical mechanisms potentially structuring reproductive habitat suitability (with example application to European anchovy, Engraulis encrasicolus). Fish Oceanogr 11:129-142

Bautista B, Jiménez-Gómez F (1996) Ultraphytoplankton photoacclimation through flow cytometry and pigment analysis of Mediterranean coastal waters. Sci Mar 60: 233-241

Berner TZ, Dubinsky Z, Wyman K, Falkowski PG (1989) Photoadaptation and the 'package' effect in Dunaliella tertiolecta (Chlorophyceae). J Phycol 25:70-78

Brzezinski MA (1985) The Si:C:N ratio of marine diatoms: interspecific variability and the effect of some environmental variables. J Phycol 21:347-357

Cano N, Lafuente G (1991) Corrientes en el litoral malagueño. Baja frecuencia. Bol Inst Esp Oceanogr 7:59-77

Cheney RE, Doblar RA (1982) Structure and variability of the Alboran Sea frontal system. J Geophys Res 87:585-594

Dauchez S, Legendre L, Fortier L, Levasseur M (1996) Nitrate uptake by size fractionated phytoplankton on the Scotian Shelf (eastern Canada): spatial and temporal variability. J Plankton Res 18:577-595

Dortch Q, Postel JR (1989) Phytoplankton-nitrogen interactions. In: Landry MR, Hickey BM (eds) Coastal oceanography of Washington and Oregon. Elsevier Oceanogr Ser 47:139-175

Dugdale RC, Goering JJ (1967) Nutrient limitation in the sea: dynamics, identification, and significance. Limnol Oceanogr 12:685-695

Dugdale RC, Wilkerson FP (1986) The use of ${ }^{15} \mathrm{~N}$ measure nitrogen uptake in eutrophic oceans: experimental considerations. Limnol Oceanogr 31:673-689

Dugdale RC, Wilkerson FP (1991) Low specific nitrate ratea common feature of high-nutrient low-chlorophyll marine ecosystems. Limnol Oceanogr 36:1678-1688

Dugdale RC, Wilkerson FP, Hogue VE, Marchi A (2006) Nutrients controls on new production in the Bodega Bay, California, coastal upwelling plume. Deep-Sea Res II 53: 3049-3062

Furnas MJ (1983) Community structure, biomass and productivity of size-fractioned summer phytoplankton populations in lower Narragansett Bay, Rhode Island. J Plankton Res 5:637-655

García-Górriz E, Carr ME (2001) Physical control of phytoplankton distributions in the Alboran Sea: a numerical and satellite approach. J Geophys Res 106:16795-16805

García-Lafuente J, Vargas JM, Candela J, Bascheck B, Plaza F, Sarchan T (2000) The tide at the eastern section of the Strait of Gibraltar. J Geophys Res 105C6:14197-14213

Glibert PM, Goldman JC (1981) Rapid ammonium uptake by marine phytoplankton. Mar Biol Lett 2:25-31

Glibert PM, Garside C, Fuhrman JA, Roman MR (1991) Timedependent coupling of inorganic and organic nitrogen uptake and regeneration in the plume of the Chesapeake Bay estuary and its regulation by large heterotrophs. Limnol Oceanogr 36:895-909

Goeyens L, Kindermans N, Yusuf MA, Elskens M (1998) A room temperature procedure for the manual determination of urea in seawater. Estuar Coast Shelf Sci 47:415-418

Goldman JC (1993) Potential role of large oceanic diatoms in new primary production. Deep-Sea Res I 40:159-168

> Gómez F, González N, Echevarría F, García CM (2000) Distribution and fluxes of dissolved nutrients in the Strait of Gibraltar and its relationships to microphytoplankton biomass. Estuar Coast Shelf Sci 51:439-449

Grasshoff WK, Weinheim K, Ehrhasrdt M, Krempling K (1983) Methods of seawater analysis, 2nd revised and extended edn. Verlag Chemie, Weinheim

Harrison W, Wood LJE (1988) Inorganic nitrogen uptake by marine picoplankton: evidence for size partitioning. Limnol Oceanogr 33:235-248

Harrison WG, Platt T, Lewis MR (1987) F-ratio and its relationship to ambient nitrate concentration in coastal waters. J Plankton Res 9:235-248

$>$ Kanda J, Laws EA, Saino T, Hattori A (1987) An evaluation of isotope dilution from conventional data sets of ${ }^{15} \mathrm{~N}$ uptake experiments. J Plankton Res 9:79-90

Kara AB, Rochford PA, Hulburt HE (2000) Efficient and accurate bulk parameterizations of air-sea fluxes for use in general circulation models. J Atmos Ocean Tech 17:1421-1438

Knap A, Michaels A, Close A, Ducklow H, Dickson A (1996) Protocols for the Joint Global Ocean Flux Study (JGOFS) core measurements. JGOFS Report No. 19. UNESCO, Paris

L'Helguen SL, LeCorre P, Morin P (2002) New and regenerated production in the Almeria-Oran front area, eastern Alboran Sea. Deep-Sea Res I 49:83-99

$>$ LeBouteiller A (1986) Environmental control of nitrate and ammonium uptake by phytoplankton in the Equatorial Atlantic Ocean. Mar Ecol Prog Ser 30:167-179

LeCorre P, Lhelguen S, Wafar M (1993) Nitrogen-source for uptake by Gyrodinium cf. aureolum in a tidal front. Limnol Oceanogr 38:446-451

MacIsaac JJ, Dugdale RC (1972) Interactions of light and inorganic nitrogen in controlling nitrogen uptake in the sea. Deep-Sea Res 19:209-232 
MacIsaac JJ, Dugdale RC, Barber RT, Blasco D, Packard TT (1985) Primary production cycle in an upwelling center. Deep-Sea Res A 32:503-529

McCarthy JJ, Nevins JL (1986) Sources of nitrogen for primary production in warm-core rings 79-E and 81-D. Limnol Oceanogr 31:690-700

Mercado JM, Ramírez T, Cortés D, Sebastián M, Vargas M (2005) Temporal changes of the phytoplankton communities in an upwelling area of the Alboran Sea. Sci Mar 69: 451-465

Mercado JM, Ramírez T, Cortés D, Sebastián M, Reul A, Bautista B (2006) Diurnal changes in the bio-optical properties of the phytoplankton in the Alboran Sea (Mediterranean Sea). Estuar Coast Shelf Sci 69:459-470

Mercado JM, Cortés D, García A, Ramírez T (2007) Seasonal and inter-annual changes in the planktonic communities of the northwest Alboran Sea (Mediterranean Sea). Prog Oceanogr 74:273-293

Minas HJ, Coste B, LeCorre P, Minas M, Raimbault P (1991) Biological and geochemical signatures associated with the water circulation through the Strait of Gibraltar and in the western Alboran Sea. J Geophys Res 96:8755-8771

Morel A, Berthon JF (1989) Surface pigments, algal biomass profiles, and potential production of the euphotic layer. Relationships reinvestigated in view of remote sensing applications. Limnol Oceanogr 34:1545-1562

Mulvenna PF, Savidge G (1992) A modified manual method for the determination of urea in seawater using diacetylmonoxime reagent. Estuar Coast Shelf Sci 34:429-438

- Neveux J, Dupouy C, Blanchot J, LeBouteiller A, Landry MR, Brown SL (2003) Diel dynamics of chlorophylls in high-nutrient, low-chlorophyll waters of the equatorial pacific $\left(180^{\circ}\right)$ : interactions of growth, grazing, physiological responses, and mixing. J Geophys Res 108(C12): 8140, doi: 10.1029/2005C000747

Owens NJP, Burkill PH, Mantoura RFC, Woodward EMS and others (1993) Size-fractionated primary production and nitrogen assimilation in the northwestern Indian Ocean. Deep-Sea Res II 40:679-709

Packard T, Chen W, Blasco D, Savenkoff C and others (2000) Dissolved organic carbon in the Gulf of St. Lawrence. Deep-Sea Res II 47:435-459

Parrilla G, Kinder TH (1987) Oceanografía física del Mar de Alborán. Bol Inst Esp Oceanogr 4:133-165

Probyn TA (1988) Nitrogen utilization by phytoplankton in the Namibian upwelling region during an austral spring. Deep-Sea Res A 35:1387-1404

Raimbault P, Slawyk G, Arcia N (2000) Comparison between chemical and isotopic measurements of biological nitrate utilization: further evidence of low new-production levels in the equatorial Pacific. Mar Biol 136:1147-1155

Ramírez T, Cortés D, Mercado JM, Vargas-Yáñez M, Sebastián M, Liger E (2005) Seasonal dynamics of inorganic nutrients and phytoplankton biomass in the NW Alboran Sea. Estuar Coast Shelf Sci 65:654-670

Editorial responsibility: Matthias Seaman, Oldendorf/Luhe, Germany
Ramírez T, Liger E, Cortés D, Mercado JM, Vargas M, Sebastián M (2006) Electron transport system activity in an upwelling area of the NW Alboran Sea. J Plankton Res 65:654-670

Redfield AC, Ketchum BH, Richards FA (1963) The influence of organisms on the composition of sea-water. In: Hill MN (ed) The sea. Interscience, New York

Reul A, Rodríguez V, Jiménez-Gómez F, Blanco JM and others (2005) Variability in the spatio-temporal distribution and size-structure of phytoplankton across an upwelling area in the NW-Alboran Sea (W-Mediterranean). Cont Shelf Res 25:589-608

Rodríguez V, Blanco JM, Jiménez-Gómez F, Rodríguez J, Echevarría F, Guerrero F (1997) Distribución espacial de algunos estimadores de biomasa fitoplanctónica y material orgánico particulado en el mar de Alborán, en condiciones de estratificación térmica (julio de 1993). Publ Espec Inst Esp Oceanogr 24:53-64

Rodríguez V, Blanco JM, Jiménez-Gómez F, Rodríguez J, Echevarria F, Guerrero F (1998) Patterns in the size structure of the phytoplankton community in the deep fluorescence maximum of the Alborán Sea (southwestern Mediterranean). Deep-Sea Res I 45:1577-1593

Ros M, Miracle MR (1984) Distribución temporal de las dinoflageladas del Mar Menor. Ann Biol 2:169-180

Savenkoff C, Chanut JP, Vezina AF, Gratton Y (1995) Distribution of biological-activity in the lower St. Lawrence estuary as determined by multivariate analysis. Estuar Coast Shelf Sci 40:647-664

Stramski D, Sciandra A, Claustre H (2002) Effects of temperature, nitrogen, and light limitation on the optical properties of the marine diatom Thalassiosira pseudonana. Limnol Oceanogr 47:392-403

Tintoré J, Gomis D, Alonso S, Parrilla G (1991) Mesoscale dynamics and vertical motion in the Alboran Sea. J Phys Oceanogr 21:811-823

Tremblay JE, Legendre L, Therriault JC (1997) Size-differential effects of vertical stability on the biomass and production of phytoplankton in a large estuarine system. Estuar Coast Shelf Sci 45:415-431

Utermohl H (1958) Zur Vervollkommnung der quantitativen Phytoplankton-Methodik. Mitt Int Ver Theor Angew Limnol 9:1-38

Videau C, Sournia A, Prieur L, Fiala M (1994) Phytoplankton and primary production characteristics at selected sites in the geostrophic Almeria-Oran front system. J Mar Syst 5: 235-250

> Watts LJ, Owens NJP (1999) Nitrogen assimilation and the $f$-ratio in the northwestern Indian Ocean during an intermonsoon period. Deep-Sea Res II 46:725-743

Yentsch CS, Menzel DW (1963) A method for the determination of phytoplankton chlorophyll and phaeophytin by fluorescence. Deep-Sea Res 63:221-231

Zar JH (1984) Biostatistical analysis. Prentice Hall, Englewood Cliffs, NJ

Submitted: August 2, 2007; Accepted: January 23, 2008 Proofs received from author(s): April 23, 2008 